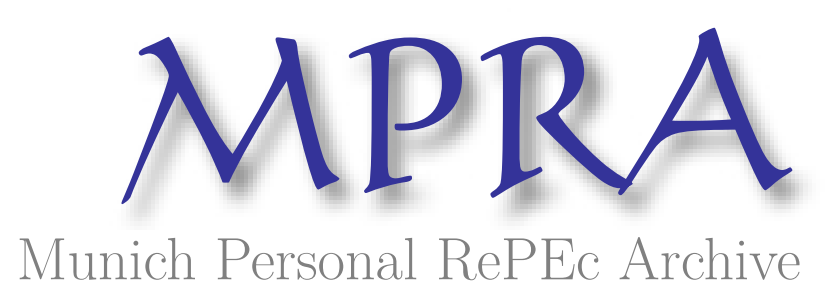

\title{
The Welfare of Children in Central India: Econometric Analysis and Policy Simulation
}

\author{
Borooah, Vani \\ Universty of Ulster
}

1999

Online at https://mpra.ub.uni-muenchen.de/75703/

MPRA Paper No. 75703, posted 22 Dec 2016 06:32 UTC 


\title{
The Welfare of Children in Central India: Econometric Analysis and Policy Simulation
}

\author{
VANI K. BOROOAH
}

ABSTRACT Among the many indicators of child welfare, rates of child and infant mortality and the prevalance of child labour are especially important, particularly in the context of developing countries. This paper estimates and simulates a model of child welfare based on recently released data for the Indian state of Madhya Pradesh. The results show that some policies, like raising female literacy rates or reducing inequality in land holdings, could have unexpected effects, while the effects of other policies, like reducing poverty or improving infrastructure, are more predictable.

\section{Introduction}

Among the many indicators of child welfare, two are particularly important: the rates of infant and child mortality; and the prevalence of child labour. In 1996, the infant (under one) and child (under five) mortality rates in developing countries varied from, respectively, nine and 10 deaths per 1000 live births in Cyprus to, respectively, 191 and 320 deaths per 1000 live births in Niger (United Nations Development Programme, 1998). The average infant and child mortality rates for the OECD countries were, respectively, 13 and 15, and the corresponding numbers for developing countries were 65 and 95 (United Nations Development Programme, 1998, Table 12). As regards child labour, according to the International Labour Office (Ashagrie, 1993) there were almost 79 million children in the world (representing nearly $14 \%$ of children in the 10-14 years age group), mostly living in developing countries, who did regular work. The proportion of this age group that worked (the "participation rate") was as high as 33\% in some African countries (Ashagrie, 1993, Table 4).

Each of these aspects of child welfare has, separately, attracted considerable academic research. In the area of mortality rates, to take but a few examples: Lee et al. (1997) examined the effects of nutrition, sanitation and water quality on the health of children in high mortality regions; LeGrand \& Phillips (1996) studied the effects of fertility reductions on infant and child mortality; Pattnaik (1995) investigated the effects of women's status on infant mortality and on birth rates; and Drèze et al. (1995) and Murthi et al. (1995) investigated the effects of women's empowerment on fertility and on child mortality rates. In the area of child labour, again to take a few examples: Basu \& Van (1998) showed that labour markets could be characterized by multiple

Vani K. Borooah, School of Public Policy, Economics and Law, University of Ulster, Newtownabbey, Northern Ireland BT37 0QB

I am grateful to Thankum and Shoba Arun and to two anonymous referees for several valuable comments on an earlier version of the paper. Needless to say, Ialone am responsible for its deficiencies. 


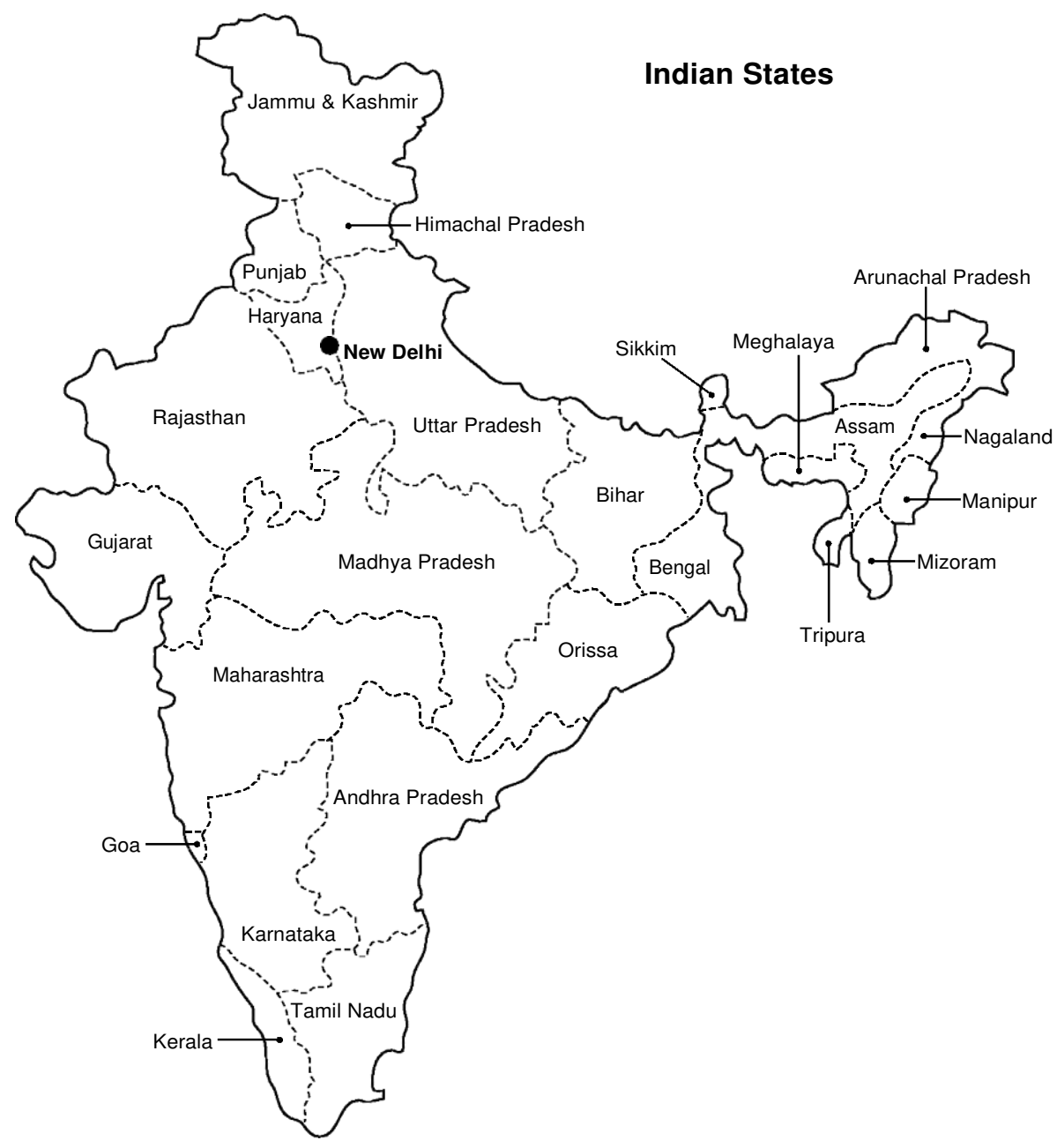

Figure 1. Political map of India.

equilibria - one in which wages were low and children worked and another in which wages were high and children did not work; White (1996) studied the effects of globalization on child labour; and Mahmood et al. (1994) and Weiner (1991) examined the issues surrounding child labour in, respectively, Pakistan and India. Against this background, the purpose of this paper is to present econometric estimates and simulation results for a model of child welfare, the empirical base of which is data, recently released, for the Indian state of Madhya Pradesh (literally "Central Province") and its districts. The accompanying maps (Figures 1 and 2) locate the state on the Indian sub-continent and identify its districts.

Madhya Pradesh is the largest of the Indian states and, with a population of nearly 70 million, is the sixth most populous. Nearly one-third of its area is forested (with teak, sal, bamboo and salai being particularly important), with another $46 \%$ devoted to agriculture. The state's land use pattern is reflected in its employment structure: $52 \%$ of its main workers are cultivators with an additional $25 \%$ working as agricultural 


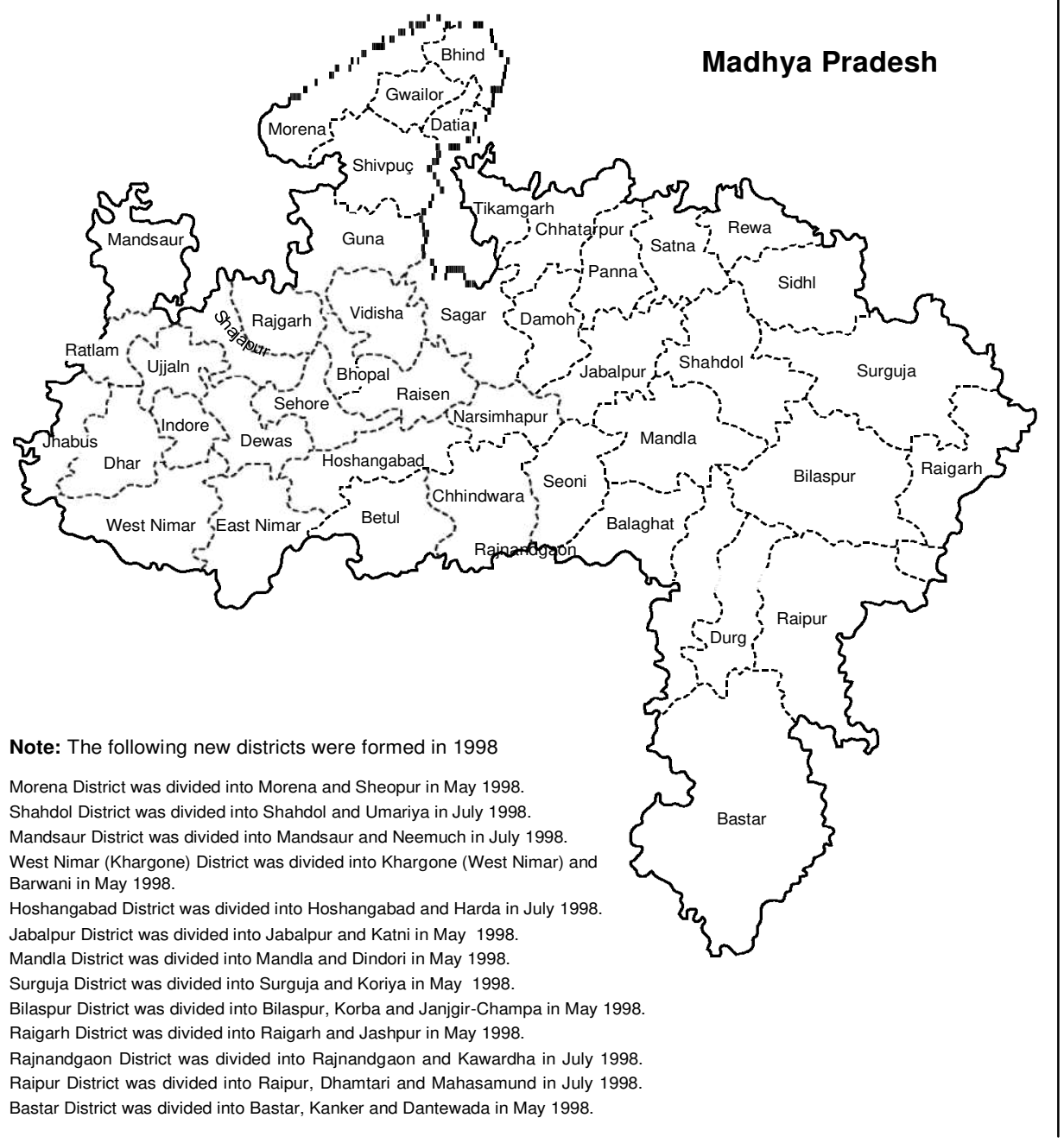

Figure 2. Map of Madhya Pradesh.

(including forestry) labourers. In addition to agriculture and forestry, livestock and poultry farming is an important economic activity. Although the state is rich in minerals these resources have not, as yet, been fully exploited and mining accounts for less than $1 \%$ of the state's workforce.

The states of Bihar, Madhya Pradesh, Rajasthan and Uttar Pradesh are, because of their low level of "human development", pejoratively referred to in India by the acronym BIMARU. ${ }^{1}$ In all these states, levels of welfare for women and children are considerably lower than elsewhere in India and, in particular, they are characterized by: low rates of female literacy; high rates of child, infant and perinatal mortality; high rates of child participation; high fertility rates and a high proportion of higher-order births; and high rates of women dying during childbirth. To speak of these states as BIMARU states is, however, not to imply that they are content to remain so. The Government of Madhya Pradesh (1998), in particular, by publishing a Human Development Report for the state, containing inter alia a wealth of district-level data on the state, has both 
painted a detailed portrait of the state and also signalled its commitment to improving upon its current low level of human development.

This report presents, for each of the state's 45 districts, detailed data for 1991 under the following broad headings: human development indices; population; gender; health; education; basic amenities; land ownership and land use; food; employment; habitat; infrastructure and facilities. From this data, we know, for example: the proportion of houses in a district which were without adequate roofing or without electricity/water/ toilet facilities or did not have access to safe drinking water (habitat); the educational achievements of persons in different districts in terms of literacy and in terms of educational level (education); the health infrastructure in different districts in terms of the availability of medical facilities and the health status of persons in the districts (health); the district-wise proportions of children and women who worked (employment); the average age of women at marriage and their childbearing experience by district (gender). In describing the data it should be stressed that these examples constitute but a small fraction of the material contained in the report.

This paper uses some of the report's data to analyse the welfare of children in Madhya Pradesh (MP). The analysis is underpinned by a seven-equation econometric model, the novelty of which is that it links the welfare of children to circumstances surrounding the lives of adults. These are: adult literacy, both male and female; the reproductive behaviour of women; the participation by women in the workforce; levels of poverty and inequality. All these circumstances interact so as to affect the mortality rates of children and their participation in the labour market. Thus, a common set of explanatory factors draws together the two, seemingly disparate, aspects of child welfare: mortality and participation. The joint analysis of child mortality and child participation contrasts with the fact that they have, as noted above, usually been studied as separate issues. The econometric framework offers the policy-maker a number of policy levers; hence policy simulations, using these estimates, explore the effects on child welfare, and on other related variables, of pulling these levers. The next section sets out the equation specifications. Section 4 discusses the estimation results, Section 5 describes the policy simulations and Section 6 concludes the paper.

The structure of the paper may be viewed in terms of three, overlapping, perspectives. The first is the specification of the econometric equations. Although "economic theory" provides the main guide to the specifications, it is deficient in two respects. First, theory may unambiguously predict the direction of the relationship between two variables but be unable to provide guidance as to the precise form of the variables. For example, on theoretical grounds, one might expect that women and children belonging to "badly-off" households would be more inclined to work than their counterparts in better-off households, without being able to say how "badly-off" ought to be defined. Making operational the concept of "badly-off" then becomes an empirical matter: it is very possible that a particular definition of being "badly-off" is empirically appropriate for women's workforce participation but that a different definition is appropriate for explaining children's participation. Second, theory may not even be able to offer an unambiguous guide to the direction of relationships. For example, literacy, by expanding employment opportunities, might mean that literate women were more likely to work than illiterate women; on the other hand, illiterate women by belonging to relatively more deprived households might, for reasons of need, be more likely to work. In such instances the direction of the relation is an empirical matter.

The second aspect of the paper is to explore, through econometric estimation, the role of specific independent variables in determining the welfare of children. This aspect draws upon the general equation specifications but hones these specifications to 
give them an empirical "cutting-edge". This essentially means three things. First, certain variables which a priori might have seemed important influences on child welfare could be found to be empirically insignificant. In effect, the original specifications are pared to their empirical essentials. Second, as noted above, general theoretical concepts are made operational by attaching to them specific, data-based, variables. In so doing, the variables that breathe life into a particular concept may differ from one context to another. The estimation of the equations reveals the nature of-though, not necessarily, the reasons for-these differences. Lastly, the theoretical indeterminacy of the direction of certain relationships is resolved empirically. In so doing it should be emphasized that this resolution is achieved through a measurement of the net effect of opposing forces: the econometric estimates are a comment on relative $(X$, pulling in one direction, is relatively more important than $Y$, pulling in another), not on absolute ( $X$ is important and $Y$ is not), magnitudes.

The third aspect of the paper is concerned with policy: what should policy-makers do to enhance the welfare of children? This question is sought to be answered through a sequence of simulations, with each successive simulation considering the effects of a change in a single policy instrument on children's welfare, while incorporating the policy changes made in the preceding simulations. In particular, the simulations explore the effects of policies to: raise literacy rates; reduce poverty and inequality; and improve infrastructure, particularly in terms of improving access to safe drinking water and to health-centre facilities. These simulations draw upon the econometric specification and estimates in that the quantitative effect of a particular policy change depends upon how, and with what strength, the policy change feeds through the system. This, in turn, depends on the structure of the system as well as upon the econometric estimates that underpin the structure.

\section{The Econometric Model}

The econometric model used to analyse the welfare of children comprised seven equations whose dependent variables were:

- children's participation in the workforce as main or as marginal workers $(C P 1)$;

- children's participation in the workforce as main workers (CP2);

- women's participation in the workforce $(F P R)$;

- child mortality rate $(C M R)$;

- infant mortality rate $(I M R)$;

- births of order 4 or greater (BO4);

- total fertility rate (TFR);

The specification of these equations is discussed below.

\subsection{Children in the Workforce}

In 1991, nearly 1 million children in Madhya Pradesh (constituting 6\% of its child population) were employed as main workers and another 350000 children were employed as marginal workers. In total, therefore, $8 \%$ of children in Madhya Pradesh were working, either as main or as marginal workers. The child participation rate-that is, the percentage of children, 5-14 years of age, employed as main or marginal workers $(C P 1)$ or simply as main workers $(C P 2)$ - varied according to district. In Jhabuawhich had the lowest per capita income in Madhya Pradesh, with nearly one-third of its population being below the poverty line, and where nearly $86 \%$ of the population 
belonged to the scheduled tribes-over $25 \%$ of children worked and $15 \%$ of children worked as main workers. On the other hand, in more prosperous districts, with relatively small scheduled tribe populations (Bhopal, Gwalior, Indore), less than 3\% of children worked. This is consistent with the fact that the children of the non-poor seldom work, even in poor countries (Basu \& Van, 1998). The participation rate of children in the workforce was, therefore, hypothesized to depend upon three factors: the economic need for children to work; parental awareness that children should not work; and "cultural" attitudes towards child labour.

Economic need was regarded as depending upon three factors. First, it was assumed that in a household model of labour market participation, members of the household joined the workforce sequentially in the order: husband, wife, children. The basic motivation for women to work was economic necessity and, as a family's economic necessity increased, children were also pressed into the workforce. Consequently, the expectation was that districts with high rates of women's workforce participation $(F P R)$ would also have high rates of child participation. The second factor determining the child participation rate was the level of poverty, with the expectation that districts with higher levels of poverty $(\mathrm{POV})$ - as measured by the proportion of their population below the poverty line-would also have high participation rates. The third factor determining the need for children to work was through the importance, in agriculture, of child labour on small family-owned plots. The hypothesis was that the smaller the degree of inequality in the distribution of $\operatorname{land}^{2}(I N Q)$, the greater would the preponderance of small holdings and, therefore, the higher would be the rate of child participation.

In the context of child labour, it was the parents who decided whether or not a child worked. Awareness of the importance of full-time education for children was measured by the male and female literacy rates ( $L T M$ and $L T F$, respectively), the expectation being that districts with higher levels of literacy would have lower rates of child participation. Literacy rates for men and for women varied considerably by district: for example, Bastar, Jhabua, Guna, Rajgarh and Sarguja had low rates of literacy-with less than one in five female, and less than one in two male, literates-while in Bhopal, Indore, Gwalior and Jabalpur over $40 \%$ of the female population and over $70 \%$ of the male population were literate.

Lastly, "cultural" attitudes towards child labour were proxied by the proportion of a district's population that were from the "scheduled" tribes (ST) and from the "scheduled" castes $(S C) .{ }^{3}$ Not only are persons belonging to these groups among the most disadvantaged in Indian society, but also they could, by virtue of their social and physical isolation, be justly described as being excluded from, or on the margins of, "mainstream" society. One consequence of such marginalization is that the cultural norms of scheduled caste and scheduled tribe persons could be, possibly are, different from those of caste Hindus. For example, it is accepted that, in Northern India, the patriarchal tradition-with all its unsavoury connotations in terms of inter alia female infanticide, child marriage, dowry - is stronger among the martial castes than among the scheduled castes (Drèze \& Sen, 1999). Equally, it is possible that generations of poverty and oppression have not only dulled scheduled tribe/caste sensibilities to the undesirability of sending children to work, it may also have led to an atitutde where the desirability of children stems precisely from the fact that they represent a supply of labour. Needless to say, this view of children as a source of earnings, far from being unique to scheduled tribe/caste households, may also be that taken by poor caste Hindus. In terms of cultural attitudes towards child labour, the difference between scheduled tribes and scheduled castes on the one hand and "mainstream" society on the other that is being expressed here is one of degree, not of kind.

Scheduled tribes and scheduled castes, in 1991, constituted, respectively, 23 and 
$15 \%$ of the population in Madhya Pradesh and thus, in a very real sense, a sharp social cleavage separated a sizeable minority of the state's population from the majority. Persons belonging to the scheduled tribes were relatively concentrated in a few districts: $85 \%$ of the population in Jhabua, $67 \%$ of the Bastar population and over half the population in Dhar, Sarguja and Mandla were from the scheduled tribes, while scheduled tribe persons constituted less than one-tenth of the population in 15 of the 45 districts in Madhya Pradesh. The distribution of scheduled castes was more even: in only eight of the 45 districts (these happening to be districts that were scheduled tribe-dominated) was the scheduled caste population share less than $10 \%$ and the highest scheduled caste population shares-in Datia, Ujjain and Chhatarpur-never exceeded $25 \%$ for any district. A characteristic of the scheduled tribe population in Madhya Pradesh, not shared by its scheduled caste population, is its low rate of urbanization-less than $5 \%$ of the scheduled tribe population, in contrast to $22 \%$ of scheduled caste population and $23 \%$ of the total population, lived in urban areas.

Against this background, the equations for child participation were specified as:

$$
\begin{aligned}
& C P 1_{i} 5 \mathrm{a}_{10} 1 \mathrm{a}_{11} L T M_{i} 1 \mathrm{a}_{12} L T F_{i} 1 \mathrm{a}_{13} F P R_{i} 1 \mathrm{a}_{14} P O V_{i} 1 \mathrm{a}_{15} I N Q_{i} 1 \mathrm{a}_{16} S C_{i} 1 \mathrm{a}_{17} S T_{i} \\
& \begin{array}{llllll}
1 & u_{1 i}
\end{array} \\
& C P 2_{i} 5 \mathrm{a}_{20} 1 \mathrm{a}_{21} L T M_{i} 1 \mathrm{a}_{22} L T F_{i} 1 \mathrm{a}_{23} F P R_{i} 1 \mathrm{a}_{24} P O V_{i} 1 \mathrm{a}_{25} I N Q_{i} 1 \mathrm{a}_{26} S C_{i} 1 \mathrm{a}_{27} S T_{i} \\
& \begin{array}{llll}
1 & u_{2 i} & \text { (2) }
\end{array}
\end{aligned}
$$

where the subscript $i$ extended over the 45 districts of Madhya Pradesh and the $u_{1 i}$ and $u_{2 i}$ were the relevant error terms.

\subsection{Women in the Workforce}

In 1991, one-third of women, compared to 52\% of men, in Madhya Pradesh were in the workforce. As with children, the worker participation rate of women $(F P R)$ varied considerably by district from around $50 \%$ in certain districts (Jhabua, Rajnandgaon, Bastar) to around $10 \%$ in others (Bhind, Morena, Gwalior, Bhopal). Women's participation was hypothesized to depend upon the need and opportunity for employment, these factors underpinned by cultural attitudes towards women working. Need was measured by a district's per capita income (YPC). It was expected that districts with lower levels of per capita income would have higher rates of female worker participation. Opportunity was measured by the fertility rate $(T F R)$ : the higher the fertility rate, the greater the demand that childcare would place on women's time and, therefore, the smaller, in terms of availability for employment, would be their employment opportunities. Consequently, districts characterized by relatively high fertility rates would have relatively low rates of women's participation, though such an assertion needs to be qualified in two important respects. First, there is the possibility of working mothers using their older children-particularly girls-to look after their younger siblings; second, there is the possibility that the children of working women could accompany their mothers to the workplace.

The female literacy rate $(L T F)$ was also included as an explanatory variable in the women's participation equation. On the one hand, higher rates of female literacy could be viewed as expanding employment opportunities for women. On the other hand, if women, at least in the cultural context of Madhya Pradesh, worked largely because they needed, rather than wanted, to work then women workers would, to a relatively greater degree, be drawn from the ranks of illiterate women since the burden of economic need could be reasonably expected to weigh relatively heavily on such women. For these reasons, while one might expect a significant association in the districts between their 
women's participation and literacy rates, it is difficult to predict the direction of this association. A cultural anchor to the equation, in terms of social attitudes towards women's participation, was provided by: (i) the $S C$ and $S T$ variables (discussed earlier); and (ii) two dummy variables, $D U M$ and $D U M B$. The variable DUM 51 for Bhopal, Indore and Morena, where women's participation, relative to other Madhya Pradesh districts, was low, DUM 5 0, elsewhere; and DUMB 51 for Bhind where women's participation, relative to other Madhya Pradesh districts, was very low (4\%), $D U M B 5$ 0, elsewhere. These districts, possibly because their populations were largely of the martial castes (Kshatriya et al.), were characterized by a "fierce patriarchy" (Drèze \& Sen, 1999), which inter alia frowned upon women working. These districts, therefore, represented outliers in the usual pattern of women's workforce participation across the other districts of Madhya Pradesh.

Against this background, the equation for the female worker participation rate was specified as:

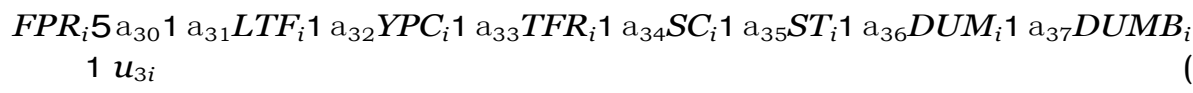

where the subscript $i$ extended over the 45 districts of Madhya Pradesh and $u_{3 i}$ was the error term associated with the equation.

\subsection{Child and Infant Mortality}

By any standards, child $(C M R)$ and infant $(I M R)$ mortality rates (defined, respectively, as mortality at age 5 and age 1, per 1000 of live births) in Madhya Pradesh are extremely high. Even more alarmingly, behind these high rates for the state as a whole, certain districts in Madhya Pradesh have even higher rates of child and infant mortality. Thus, in 1991, when the infant mortality rate in the state was 133 per thousand and the child mortality rate was 147 per thousand, seven districts had infant mortality rates in excess of 140 and 10 districts had child mortality rates in excess of 175 . Both child and infant mortality rates were hypothesized to depend upon five factors: (i) the quality of the child/infant's physical environment; (ii) the availability of medical facilities; (iii) the economic condition of households; (iv) the quality of maternal care received by the child/infant; and (v) cultural influences affecting mortality.

The quality of the child's physical environment was measured by two variables: the percentage of households in a district with access to safe drinking water $(D R W)$ and the percentage of households in a district whose dwellings had "inadequate" roofing ${ }^{4}$ $(R O O F)$. The quality of roofing material is the most useful indicator of the degree of protection that households obtain from the weather and other external elements: $5 \%$ of households in Madhya Pradesh (though this was as high as 20\% in Bastar and Bhind) lived in dwellings with inadequate roofing. The importance of access to safe drinking water does not need to be emphasized. In Madhya Pradesh, on average, $53 \%$ of households had access to safe drinking water and this comprised $80 \%$ of its urban households and $46 \%$ of its rural households. The average figure, however, masked considerable differences between the districts: only $27 \%$ of households in Jhabua, but $89 \%$ of households in Gwalior and Indore, had access to safe drinking water.

The availability of medical facilities in a district was measured by: (a) the number of health centres ${ }^{5}$ per $100 \mathrm{~km}^{2}$ (HCR); and (b) by the total number of medical beds per 100000 of its population $(B E D)$. The influence of economic conditions was measured by the poverty rate $(P O V)$, that is, the proportion of a district's population that is "poor". The quality of maternal care was hypothesized to depend upon the number of 
children mothers had to care for and the time that they were able to devote to their care. Consequently, districts where a relatively high percentage of births were of order 4 or more $(B O 4)$ and where a relatively high proportion of women worked $(F P R)$ would be expected to have higher rates of mortality. ${ }^{6}$ Lastly, cultural influences were proxied by the proportion of a district's population that belonged to the scheduled castes (SC) and scheduled tribes $(S T)$. The mortality equations were, against the background of this discussion, specified as:

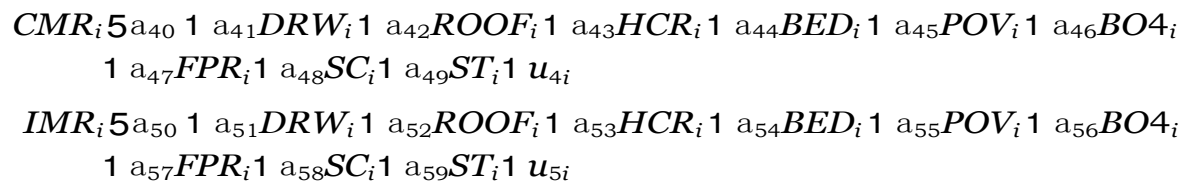

$I M R_{i} 5_{\mathrm{a}_{50}} 1 \mathrm{a}_{51} D R W_{i} 1 \mathrm{a}_{52} R O O F_{i} 1 \mathrm{a}_{53} H C R_{i} 1 \mathrm{a}_{54} B E D_{i} 1 \mathrm{a}_{55} P O V_{i} 1 \mathrm{a}_{56} B O 4_{i}$ $1 \mathrm{a}_{57} F P R_{i} 1 \mathrm{a}_{58} S C_{i} 1 \mathrm{a}_{59} S T_{i} 1 u_{5 i}$

where the subscript $i$ extended over the 45 districts of Madhya Pradesh and $u_{4 i}$ and $u_{5 i}$ were the error terms associated with the equations.

\subsection{Fertility and Higher Order Births}

The total fertility rate (TFR), defined as the average number of births per woman, in a district and the share, in total births, of births of order 4 and above (BO4) entered as explanatory variables into, respectively, equation (3) and equations (4) and (5). The model was "closed" by specifying equations for these variables. Both the fertility rate and the share of higher order births were taken to depend on the same set of factors: districts with higher rates of female literacy would have lower fertility rates and a smaller proportion of higher order births; on the other hand, given the importance in poor families of children as "providers", fertility rates and the share of higher order births would be high in districts with high poverty rates. Overlying these influences was the cultural effect of the presence, in a district's population, of persons belonging to the scheduled castes and the scheduled tribes. The two equations were, accordingly, specified as:

$$
\begin{aligned}
& T F R_{i} 5 \mathrm{a}_{60} 1 \mathrm{a}_{61} L T F_{i} 1 \mathrm{a}_{62} P O V_{i} 1 \mathrm{a}_{63} S C_{i} 1 \mathrm{a}_{64} S T_{i} 1 u_{6 i} \\
& B O 4_{i} 5 \mathrm{a}_{70} 1 \mathrm{a}_{71} L T F_{i} 1 \mathrm{a}_{72} P O V_{i} 1 \mathrm{a}_{73} S C_{i} 1 \mathrm{a}_{74} S T_{i} 1 u_{7 i}
\end{aligned}
$$

where the subscript $i$ extended over the 45 districts of Madhya Pradesh and $u_{6 i}$ and $u_{7 i}$ were the error terms associated with the equations.

\section{Estimation Results}

Equations (1)-(7) were estimated by treating them as a system of seemingly unrelated regression equations ${ }^{7}$ (SURE). As is well known, when the equations do not contain the same set of explanatory variables and when the unobserveable and omitted factors in the individual equations (encapsulated in the error vectors, $\mathbf{u}_{j} 5\left\{u_{j i}, \quad i 51, \ldots, 45\right\}$, $j 51, \ldots, 7)$ are correlated across the equations, SURE estimates are more efficient than those obtained through ordinary least squares (OLS). ${ }^{8}$ Even if, in the absence of any cross-equation correlation between the error terms, there were no efficiency gains to be reaped, SURE estimation, unlike OLS, would allow the validity of cross-equation restrictions to be tested and, where appropriate, for such restrictions to be imposed.

The estimation of the equation system ran into problems of multicollinearity with respect to two sets of variables: male and female literacy rates, whose estimated correlation coefficient was 0.88 ; and the scheduled tribe and scheduled caste district population shares, with an estimated correlation coefficient of 20.87 . Consequently, 
when $L T M$ and $L T F$ were both used as explanatory variables in equations (1) and (2), and when $S C$ and $S T$ were both used as explanatory variables in equations (1)-(7), the results were not "sensible", ${ }^{9}$ though any member of each pair, on its own, was statistically significant and plausibly signed. The solution that was adopted towards this problem was twofold. As regards the literacy rates, only the male literacy rate, LTM, was used in the child participation equations. This was done in the belief that, within the cultural context of Madhya Pradesh, the decision as to whether a child did or did not work was essentially made by the father. As regards the scheduled tribe/caste issue, two sets of results were obtained. The first set of results (shown in Table 1) controlled for the presence of scheduled tribes but not for scheduled castes (that is, used ST but not $S C$ as one of the explanatory variables in equations (1)-(7)) and the second set of results (shown in Table 2) controlled for the presence of scheduled castes but not for scheduled tribes (that is, used $S C$ but not $S T$ as one of the explanatory variables in equations (1)-(7)). For both sets of results, the Breusch-Pagan test, with ${ }_{c}^{2}(21)$ values of 102.6 and 96.0, respectively, did not accept the null hypothesis that the error terms were uncorrelated across the equations and, therefore, justified the use of SURE estimation.

It should be noted parenthetically that there was very little correlation between the four "deprivation" indicators used: $P O V ; Y P C ; D R W$; and ROOF. The correlation between the per capita income of the districts $(Y P C)$ and the proportion of their populations $(P O V)$ below the poverty line was 20.15 ; the correlation between the proportion of the population who lacked access to safe drinking water $(D R W)$ and whose dwellings had inadequate roofing $(R O O F)$ was 0.19 ; the only significantly large correlation was 0.55 between the per capita income of the districts and the proportion of their populations who lacked access to safe drinking water.

\subsection{Scheduled Tribes and Scheduled Castes}

3.1.1 Worker participation. The top panels of Tables 1 and 2 show the summary statistics for the relevant set of equations beginning with the number of observations (45, which is the number of districts in Madhya Pradesh) for each equation and the number of parameters estimated (which varies by equation). The next statistic is the root mean square error (RMSE). This is the (square root of) average of the (squared) 45 equation errors, where the error for a particular district is the difference between the actual and the predicted value of the dependent variable for that district. The $R^{2}$ statistic measures the goodness-of-fit and the $\mathrm{c}^{2}$ statistic tests the null hypothesis that all the slope coefficients are zero; the latter hypothesis was, on the basis of the computed ${ }_{\mathrm{c}}^{2}$ values, always rejected. Following the summary statistics are the equationby-equation estimation results.

The estimation results in Tables 1 and 2 show that the coefficients on the $S C$ and the $S T$ variables in all but two of the equations (1)-(7) were statistically significant but of opposing signs. This has two interesting implications. First, even after controlling for other (non-caste) factors, the proportionate presence of scheduled caste/tribe persons in a district exerted a significant influence on most of the dependent variables. Second, as Table 1 shows, the coefficient for $S T$ was positive but the coefficient for $S C$ was negative in equations (1)-(3). Ceteris paribus the presence of scheduled tribes was associated with higher, and that of scheduled castes with lower, female and child worker participation rates. This result can be understood in the context of the fact that the "untouchables" of the Indian caste system are those groups which have been recognized by the Indian government as belonging to the "scheduled castes" (Deliège, 1996). The 
Table 1. SURE estimation results: controlling for scheduled Tribes

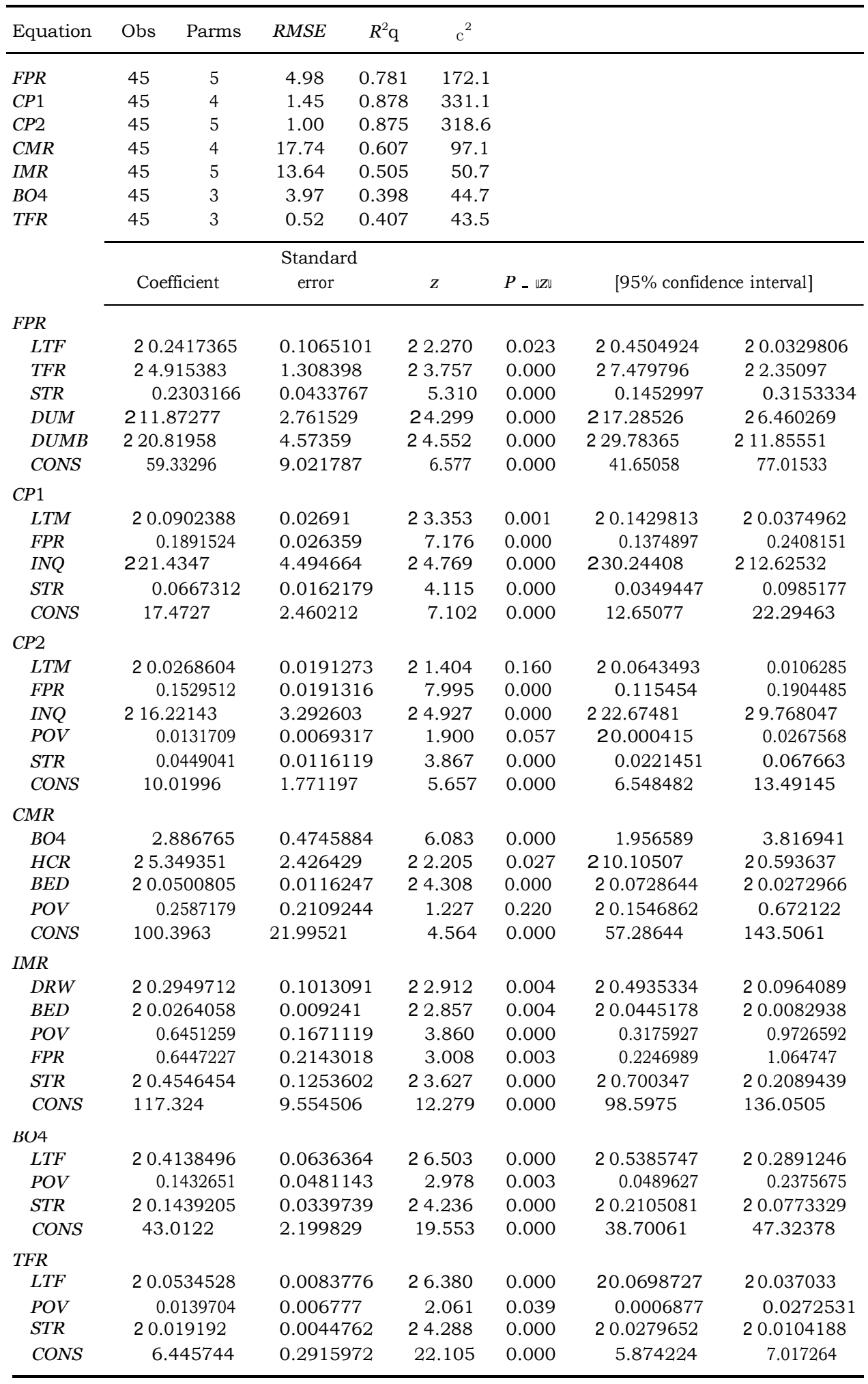


Table 2. SURE estimation results: controlling for scheduled castes

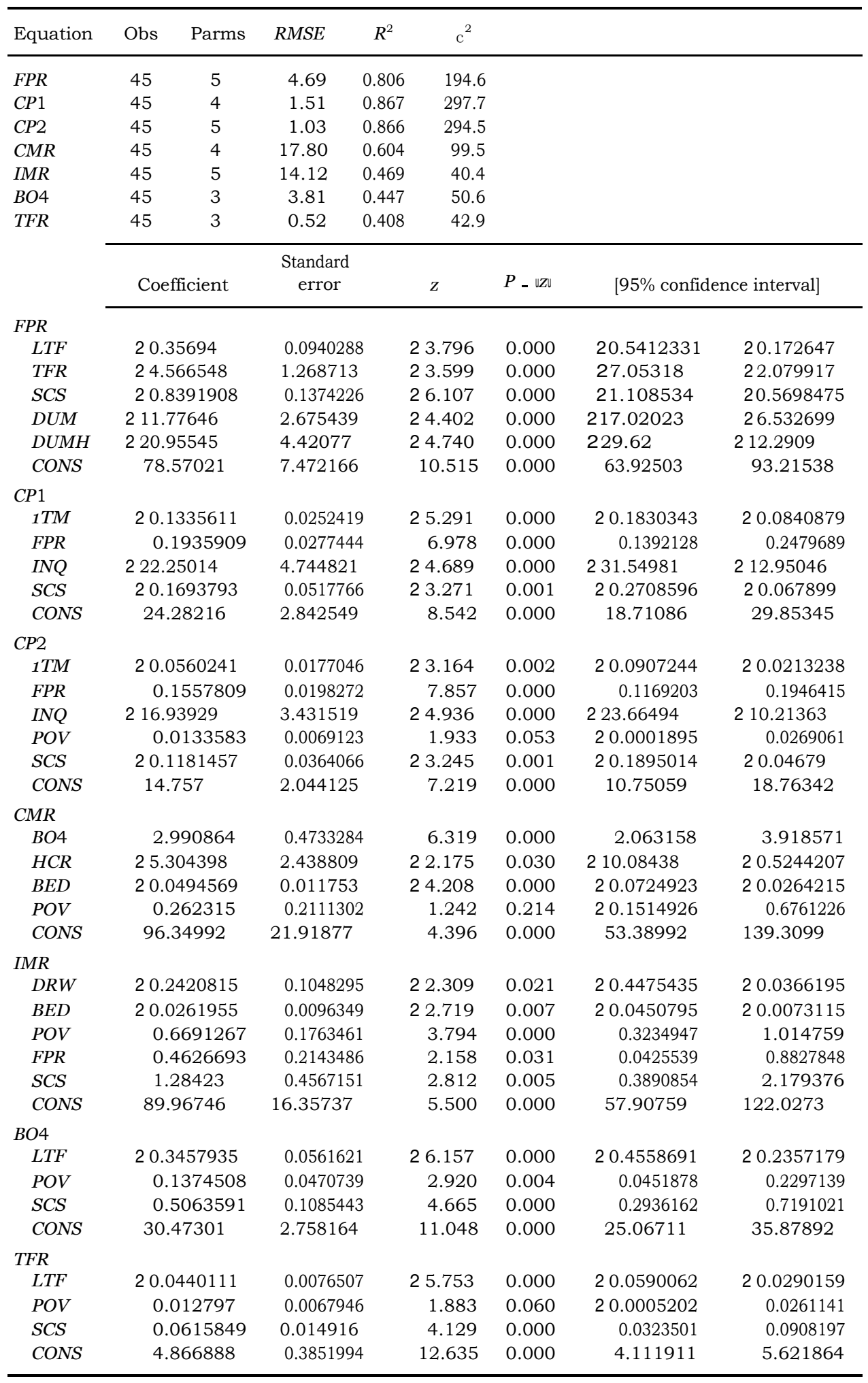


"untouchability" of these groups derived from their occupational association with death and organic waste and, given the dependence of these groups on the higher castes (Bailey, 1960) for employment, water, irrigation, housing, etc. this greatly limits the type of employment that is available to scheduled caste women and children. In particular, it rules out any employment where there is the need for, or possibility of, physical contact—albeit indirectly—between the employer and the employee. ${ }^{10}$

On the other hand, although orthodox Hindus regard some scheduled tribes as "untouchables" this would be directed towards those tribes who ate beef and pork. For example, the Bhils (who are an important scheduled tribe of Madhya Pradesh, concentrated in Jhabua district) are sufficiently integrated into mainstream Hindu society for their more aristocratic segments to be able to employ Brahmin priests. So, in terms of untouchability, scheduled tribes are less handicapped than are the scheduled castes. Persons belonging to the scheduled tribes in Madhya Pradesh have the further advantage over scheduled caste persons in that the scheduled tribes are highly concentrated in certain districts. This concentration gives them an occupational independence which the scheduled castes, who are more dispersed over the state, do not enjoy. For example, most tribals engage in agriculture, using the primitive "slash-and-burn" (jhum) method, but the scheduled castes, who are excluded from land-ownership, depend upon higher caste land owners for employment as labourers. For all these reasons, while women and children from both scheduled caste and scheduled tribe families might need to work, employment opportunities for scheduled caste women and children, compared with opportunities for women and children from the scheduled tribes are relatively restricted.

3.1.2 Child and infant mortality. The second interesting implication of the scheduled tribe/scheduled caste divide is with regard to child and infant mortality. As Tables 1 and 2 show, the coefficient on $S T$ was significantly negative, but the coefficient on $S C$ was significantly positive, in the infant mortality equation. This implies that, in terms of a district's population, a proportionately higher presence of scheduled tribes would ceteris paribus be associated with lower rates of infant mortality and a proportionately higher presence of scheduled castes would be associated with higher rates of infant mortality.

Children in poor families need to work in order to raise their family income above subsistence level. Where children are able to work-as in tribal families with their reliance on family-based agriculture for their livelihood-they are an asset and, in the allocation of family resources, emphasis is placed on their "good health". Where children are unable to find work because their employment opportunities are highly limited—as with children of scheduled caste families-family income falls below subsistence level and infant mortality rates are high.

\subsection{Poverty and Inequality}

The above discussion leads very naturally into a discussion about the roles of poverty and inequality in determining the welfare of children. The econometric estimates unambiguously showed that, after controlling for other factors, districts with relatively high poverty rates also had relatively high rates of child and of infant mortality. In addition to its effects upon mortality rates, poverty was associated with larger families: ceteris paribus districts with relatively high poverty rates had relatively high fertility rates and a relatively greater proportion, in total births, of higher order births. One expla- 
nation for the last result is that since children hold out the promise of improving family fortunes through their labour-either as children, adolescents or adults - the greater the level of poverty in a district, the more widespread would be the desire for more, rather than less, children.

The role of inequality (in the distribution of land) in affecting children's welfare was both similar and different from that of poverty, discussed above. Greater equality in the distribution of land increased the preponderance, in agriculture, of small family holdings and, since the labour of children is an important input in the operation of these holdings, raised the workforce participation rate of children. ${ }^{11}$ In this respect, increased equality, like higher levels of poverty, reduced the welfare of children.

\subsection{Male and Female Literacy Rates}

Male literacy rates had a significantly negative effect on children's workforce participation as main or as marginal workers. The male literacy effect continued to be significant for children as main workers when scheduled castes were controlled for (Table 2). However, when scheduled tribes were controlled for (Table 1), the male literacy variable, though adding to the explanatory power of equation (2), was not significantly different from zero. This suggests that when children participated as main workers they did so because of overwhelming economic need, hence a rise in the male literacy rates with, presumably, a concomitant increase in the awareness of educating children was not sufficient to obviate this. Alternatively, it could be that, in districts where scheduled tribes were an important part of the population, children who were main workers came from different (plausibly, worse-off) families than children who were marginal workers and that inter-district variations in male literacy rates did not affect fathers of the former-most of these men being illiterate, whatever their district of residence-but they did affect fathers of the latter.

Earlier, the effect on female workforce participation of higher female literacy levels was viewed agnostically. The estimates show that (irrespective of whether scheduled tribes or scheduled castes were controlled for) districts with higher rates of female literacy had lower rates of female participation. This suggests that women in Madhya Pradesh worked because they needed to rather than because they wanted to. Literate women were more likely to belong to relatively prosperous families and, therefore, less inclined to work. The effect of female literacy on mortality rates was indirect and operated through two channels: first, higher rates of literacy reduced the proportion, in total births, of higher order births and this, in turn, led to lower rates of child mortality; second, higher female literacy rates were associated with lower rates of female worker participation (both independently and through reductions in the total fertility rate) and this, in turn, led to lower rates of infant mortality.

\subsection{Health Facilities}

The availability of safe drinking water significantly reduced the infant mortality rate, though it did not have a significant affect on child mortality. Neither mortality rate was significantly affected by the absence of adequate roofing. The availability of healthcentre beds in a district played a significant role in reducing its child and infant mortality rates, but access to health centres was significant only in reducing the child mortality rate. 


\section{Policy Simulations}

The preceding discussion suggested a number of policy instruments for improving the welfare of children. This section uses the econometric estimates shown in Table 1 (that is, after controlling for the presence of persons from the scheduled tribes, since these constituted nearly one-quarter of the state's population) to assess, through a sequence of policy simulations, the efficacy of these instruments in achieving these ends. ${ }^{12}$ The policy instruments considered were:

Simulation 1: Improving literacy rates, in every district, by $8 \%$ for men and $45 \%$ for women. ${ }^{13}$

- Simulation 2 : Reducing, by $25 \%$, the poverty rate in every district.

- Simulation 3: Reducing, by 5\%, the value of the Gini coefficient in every district.

- Simulation 4: Ensuring that in every district $90 \%$ of households had access to safe drinking water.

- Simulation 5: Increasing, in every district, the number of health centres per $100 \mathrm{~km}^{2}$ by $5 \%$ and the number of beds per 100000 of population by $20 \%$.

It should be emphasized that these simulations were cumulative so that each step incorporated the changes made in the earlier simulations: the difference between two successive simulations then measured the effect of the latest policy change. ${ }^{14}$ Since the equation system had recursive aspects, in that some of the dependent variables entered as explanatory variables in other equations, ${ }^{15}$ the simulations were designed as follows. First, equations (6) and (7) were used to compute the values of TFR and BO4 under the different policy scenarios of simulations $1-5$. The computed value of $T F R$ was then used as the value of the explanatory variable in the relevant simulation for $F P R$ (equation (3)) and the computed value of $B O 4$ was similarly used for $C M R$ (equation (4)). The computed value of $F P R$ that emerged from these simulations was then used as the value of the explanatory variable in the relevant simulation for $C P 1$ and $C P 2$ (equations (1) and (2)).

Tables 3-9, respectively, show the effect of these simulations (under columns S1-S5) on: the fertility rate (TFR: Table 3); births of order 4 or more (BO4: Table 4); women's workforce participation rate (FPR: Table 5); children's workforce participation rate as main or marginal workers (CP1: Table 6); children's workforce participation rate as main workers (CP2: Table 7$)$; child mortality rate (CMR: Table 8); infant mortality rate (IMR: Table 9). In each table, the columns headed AC and PR show, respectively, the sample, and predicted, values of the relevant variable for the various districts. The predicted values under the PR column use, in all the equations, the sample values of the relevant explanatory variables. The values under the column headed SO show the predicted values computed by taking account of the recursive nature of the model, described above, but without altering the values of the policy instruments from their sample values. In other words, the predicted values under $\mathrm{S} 0$ are computed using the predicted values of TFR, BO4 and FPR in the relevant equations. These values under the SO column should, therefore, be viewed as the base simulation values against which the results shown under the subsequent columns are to be compared.

Comparing columns SO and S1 of Tables 3 and 4 shows that raising the female literacy rate (simulation 1) reduced the fertility rate and the incidence of higher order births. From equation (3), the reduced fertility rate raised female workforce participation but, the higher female literacy rate independently reduced the female participation rate. Consequently, the net effect of an increase in the female literacy rate on female 
Table 3. Simulation results for total fertility rates: controlling for scheduled tribes

\begin{tabular}{|c|c|c|c|c|c|c|c|c|}
\hline District & $\mathrm{AC}$ & PR & $\mathrm{SO}$ & $\mathrm{S} 1$ & $\mathrm{~S} 2$ & S3 & S4 & S5 \\
\hline Balaghat & 3.9 & 4.6 & 4.6 & 3.6 & 3.5 & 3.5 & 3.5 & 3.5 \\
\hline Bastar & 4.5 & 4.7 & 4.7 & 4.3 & 4.2 & 4.2 & 4.2 & 4.2 \\
\hline Betul & 5.3 & 4.8 & 4.8 & 4.0 & 3.8 & 3.8 & 3.8 & 3.8 \\
\hline Bhind & 5.6 & 5.2 & 5.2 & 4.5 & 4.5 & 4.5 & 4.5 & 4.5 \\
\hline Bhopal & 4.8 & 4.0 & 4.0 & 2.7 & 2.6 & 2.6 & 2.6 & 2.6 \\
\hline Bilaspur & 4.7 & 5.0 & 5.0 & 4.4 & 4.2 & 4.2 & 4.2 & 4.2 \\
\hline Chhatarpur & 5.6 & 5.6 & 5.6 & 5.1 & 5.0 & 5.0 & 5.0 & 5.0 \\
\hline Chhindwara & 5.2 & 4.5 & 4.5 & 3.7 & 3.6 & 3.6 & 3.6 & 3.6 \\
\hline Damoh & 5.1 & 5.4 & 5.4 & 4.6 & 4.4 & 4.4 & 4.4 & 4.4 \\
\hline Datia & 5.1 & 5.4 & 5.4 & 4.8 & 4.8 & 4.8 & 4.8 & 4.8 \\
\hline Dewas & 4.9 & 5.2 & 5.2 & 4.5 & 4.5 & 4.5 & 4.5 & 4.5 \\
\hline Dhar & 5 & 4.6 & 4.6 & 4.1 & 4.0 & 4.0 & 4.0 & 4.0 \\
\hline Durg & 4.2 & 4.3 & 4.3 & 3.3 & 3.2 & 3.2 & 3.2 & 3.2 \\
\hline Guna & 5.9 & 5.5 & 5.5 & 5.1 & 5.0 & 5.0 & 5.0 & 5.0 \\
\hline Gwalior & 4.9 & 4.5 & 4.5 & 3.5 & 3.4 & 3.4 & 3.4 & 3.4 \\
\hline Hshbad & 4.7 & 4.7 & 4.7 & 3.7 & 3.6 & 3.6 & 3.6 & 3.6 \\
\hline Indore & 3.8 & 3.9 & 3.9 & 2.7 & 2.5 & 2.5 & 2.5 & 2.5 \\
\hline Jabalpur & 4.6 & 4.3 & 4.3 & 3.2 & 3.1 & 3.1 & 3.1 & 3.1 \\
\hline Jhabua & 5.7 & 4.6 & 4.6 & 4.3 & 4.2 & 4.2 & 4.2 & 4.2 \\
\hline Mandla & 4.1 & 4.8 & 4.8 & 4.3 & 4.1 & 4.1 & 4.1 & 4.1 \\
\hline Mandsaur & 4.1 & 5.2 & 5.2 & 4.5 & 4.4 & 4.4 & 4.4 & 4.4 \\
\hline Morena & 6.6 & 5.5 & 5.5 & 5.0 & 4.9 & 4.9 & 4.9 & 4.9 \\
\hline Narsmpur & 4 & 4.3 & 4.3 & 3.3 & 3.2 & 3.2 & 3.2 & 3.2 \\
\hline NimarE & 5.2 & 4.9 & 4.9 & 4.2 & 4.0 & 4.0 & 4.0 & 4.0 \\
\hline NimarW & 5.1 & 5.4 & 5.4 & 4.8 & 4.6 & 4.6 & 4.6 & 4.6 \\
\hline Panna & 5.7 & 5.5 & 5.5 & 5.0 & 4.9 & 4.9 & 4.9 & 4.9 \\
\hline Raigarh & 4 & 4.5 & 4.5 & 3.9 & 3.8 & 3.8 & 3.8 & 3.8 \\
\hline Raipur & 4.3 & 4.8 & 4.8 & 4.1 & 4.0 & 4.0 & 4.0 & 4.0 \\
\hline Raisen & 6.1 & 5.3 & 5.3 & 4.7 & 4.6 & 4.6 & 4.6 & 4.6 \\
\hline Rajgarh & 5.2 & 5.9 & 5.9 & 5.6 & 5.5 & 5.5 & 5.5 & 5.5 \\
\hline Rajnangn & 4.2 & 4.9 & 4.9 & 4.2 & 4.1 & 4.1 & 4.1 & 4.1 \\
\hline Ratlam & 4.7 & 4.7 & 4.7 & 4.0 & 3.9 & 3.9 & 3.9 & 3.9 \\
\hline Rewa & 5.6 & 5.2 & 5.2 & 4.5 & 4.4 & 4.4 & 4.4 & 4.4 \\
\hline Sagar & 5.5 & 5.0 & 5.0 & 4.1 & 3.9 & 3.9 & 3.9 & 3.9 \\
\hline Sarguja & 4.3 & 5.0 & 5.0 & 4.6 & 4.4 & 4.4 & 4.4 & 4.4 \\
\hline Satna & 5.5 & 5.1 & 5.1 & 4.4 & 4.3 & 4.3 & 4.3 & 4.3 \\
\hline Sehore & 5.2 & 5.5 & 5.5 & 5.0 & 4.9 & 4.9 & 4.9 & 4.9 \\
\hline Seoni & 4.3 & 4.6 & 4.6 & 3.8 & 3.7 & 3.7 & 3.7 & 3.7 \\
\hline Shahdol & 5 & 4.9 & 4.9 & 4.5 & 4.4 & 4.4 & 4.4 & 4.4 \\
\hline Shajapur & 5 & 5.6 & 5.6 & 5.2 & 5.1 & 5.1 & 5.1 & 5.1 \\
\hline Shivpuri & 5.4 & 5.6 & 5.6 & 5.2 & 5.2 & 5.2 & 5.2 & 5.2 \\
\hline Sidhi & 6 & 5.6 & 5.6 & 5.3 & 5.2 & 5.2 & 5.2 & 5.2 \\
\hline Tikamgarh & 6.2 & 5.6 & 5.6 & 5.1 & 5.0 & 5.0 & 5.0 & 5.0 \\
\hline Ujjain & 4.2 & 4.9 & 4.9 & 4.2 & 4.1 & 4.1 & 4.1 & 4.1 \\
\hline Vidisha & 5.6 & 5.4 & 5.4 & 4.7 & 4.6 & 4.6 & 4.6 & 4.6 \\
\hline
\end{tabular}

workforce participation depended upon the opposing strengths of the "indirect" and "direct" effects of higher female literacy. As Table 5 shows, in all the districts, the net effect was to raise the participation rate very slightly or, in other words, the strength of the direct effect was fractionally less than that of the indirect effect.

From equation (4), the rise in female literacy, acting through the reduced proportion of higher order births, reduced the child mortality rate in all the districts (Table 
Table 4. Simulation results for higher order births: controlling for scheduled tribes

\begin{tabular}{|c|c|c|c|c|c|c|c|c|}
\hline District & $\mathrm{AC}$ & PR & So & $\mathrm{S} 1$ & $\mathrm{~S} 2$ & S3 & S4 & S5 \\
\hline Balaghat & 22.9 & 30.2 & 30.2 & 23.0 & 21.4 & 21.4 & 21.4 & 21.4 \\
\hline Bastar & 30.2 & 30.6 & 30.6 & 27.7 & 26.8 & 26.8 & 26.8 & 26.8 \\
\hline Betul & 37.7 & 33.0 & 33.0 & 26.7 & 24.3 & 24.3 & 24.3 & 24.3 \\
\hline Bhind & 37.1 & 34.3 & 34.3 & 29.0 & 28.3 & 28.3 & 28.3 & 28.3 \\
\hline Bhopal & 30 & 25.4 & 25.4 & 15.3 & 14.0 & 14.0 & 14.0 & 14.0 \\
\hline Bilaspur & 31.8 & 33.2 & 33.2 & 28.1 & 26.9 & 26.9 & 26.9 & 26.9 \\
\hline Chhatarpur & 42.2 & 37.2 & 37.2 & 33.2 & 32.3 & 32.3 & 32.3 & 32.3 \\
\hline Chhindwara & 34.8 & 29.1 & 29.1 & 23.0 & 21.9 & 21.9 & 21.9 & 21.9 \\
\hline Damoh & 35.8 & 36.5 & 36.5 & 30.9 & 28.9 & 28.9 & 28.9 & 28.9 \\
\hline Datia & 35 & 35.5 & 35.5 & 31.1 & 30.4 & 30.4 & 30.4 & 30.4 \\
\hline Dewas & 30.7 & 34.1 & 34.1 & 29.3 & 28.4 & 28.4 & 28.4 & 28.4 \\
\hline Dhar & 32.1 & 29.9 & 29.9 & 26.0 & 25.2 & 25.2 & 25.2 & 25.2 \\
\hline Durg & 25.1 & 27.6 & 27.6 & 19.6 & 18.6 & 18.6 & 18.6 & 18.6 \\
\hline Guna & 37.8 & 36.4 & 36.4 & 33.1 & 32.4 & 32.4 & 32.4 & 32.4 \\
\hline Gwalior & 28.9 & 28.8 & 28.8 & 21.0 & 20.2 & 20.2 & 20.2 & 20.2 \\
\hline Hshbad & 35.3 & 30.6 & 30.6 & 23.6 & 22.2 & 22.2 & 22.2 & 22.2 \\
\hline Indore & 23.1 & 24.8 & 24.8 & 14.9 & 13.7 & 13.7 & 13.7 & 13.7 \\
\hline Jabalpur & 31.9 & 27.9 & 27.9 & 19.5 & 18.0 & 18.0 & 18.0 & 18.0 \\
\hline Jhabua & 39.7 & 30.4 & 30.4 & 28.2 & 27.1 & 27.1 & 27.1 & 27.1 \\
\hline Mandla & 24 & 32.8 & 32.8 & 28.6 & 26.7 & 26.7 & 26.7 & 26.7 \\
\hline Mandsaur & 27.1 & 34.0 & 34.0 & 28.8 & 27.9 & 27.9 & 27.9 & 27.9 \\
\hline Morena & 41.4 & 36.5 & 36.5 & 32.7 & 31.9 & 31.9 & 31.9 & 31.9 \\
\hline Narsmpur & 27.9 & 27.2 & 27.2 & 19.5 & 18.6 & 18.6 & 18.6 & 18.6 \\
\hline NimarE & 34.4 & 33.3 & 33.3 & 27.4 & 25.6 & 25.6 & 25.6 & 25.6 \\
\hline NimarW & 34.4 & 37.6 & 37.6 & 33.3 & 30.5 & 30.5 & 30.5 & 30.5 \\
\hline Panna & 34.2 & 36.2 & 36.2 & 32.6 & 31.8 & 31.8 & 31.8 & 31.8 \\
\hline Raigarh & 25 & 29.3 & 29.3 & 24.4 & 23.3 & 23.3 & 23.3 & 23.3 \\
\hline Raipur & 29.4 & 31.3 & 31.3 & 25.5 & 24.6 & 24.6 & 24.6 & 24.6 \\
\hline Raisen & 34.6 & 35.3 & 35.3 & 30.5 & 29.3 & 29.3 & 29.3 & 29.3 \\
\hline Rajgarh & 34.2 & 40.2 & 40.2 & 37.3 & 36.2 & 36.2 & 36.2 & 36.2 \\
\hline Rajnangn & 26 & 32.0 & 32.0 & 26.8 & 25.8 & 25.8 & 25.8 & 25.8 \\
\hline Ratlam & 29.8 & 30.3 & 30.3 & 24.9 & 24.2 & 24.2 & 24.2 & 24.2 \\
\hline Rewa & 37.4 & 34.3 & 34.3 & 29.3 & 28.3 & 28.3 & 28.3 & 28.3 \\
\hline Sagar & 38.9 & 33.6 & 33.6 & 26.5 & 24.7 & 24.7 & 24.7 & 24.7 \\
\hline Sarguja & 30.1 & 33.3 & 33.3 & 30.1 & 28.8 & 28.8 & 28.8 & 28.8 \\
\hline Satna & 34.4 & 33.6 & 33.6 & 28.5 & 27.4 & 27.4 & 27.4 & 27.4 \\
\hline Sehore & 36.4 & 37.3 & 37.3 & 33.2 & 32.0 & 32.0 & 32.0 & 32.0 \\
\hline Seoni & 28.8 & 30.1 & 30.1 & 24.3 & 23.0 & 23.0 & 23.0 & 23.0 \\
\hline Shahdol & 33.4 & 32.8 & 32.8 & 29.1 & 27.9 & 27.9 & 27.9 & 27.9 \\
\hline Shajapur & 32.3 & 37.5 & 37.5 & 33.9 & 33.1 & 33.1 & 33.1 & 33.1 \\
\hline Shivpuri & 40.3 & 37.2 & 37.2 & 34.3 & 33.7 & 33.7 & 33.7 & 33.7 \\
\hline Sidhi & 39.8 & 38.2 & 38.2 & 35.7 & 34.4 & 34.4 & 34.4 & 34.4 \\
\hline Tikamgarh & 38 & 37.2 & 37.2 & 33.5 & 32.7 & 32.7 & 32.7 & 32.7 \\
\hline Ujjain & 28.7 & 32.1 & 32.1 & 26.0 & 25.3 & 25.3 & 25.3 & 25.3 \\
\hline Vidisha & 41.4 & 35.8 & 35.8 & 30.6 & 29.4 & 29.4 & 29.4 & 29.4 \\
\hline
\end{tabular}

8 ) and this reduction was quite substantial. The rise in female literacy, however, to a very small degree, raised the infant mortality rate (Table 9) and this was because, as observed in the previous paragraph, the higher female literacy rate-acting through the fertility rate-raised, very slightly, the rate of female workforce participation, leading to a fall in the amount of maternal care. Raising the male literacy rate lowered the child participation rate but this effect was dampened by the fact that simultaneously raising 
Table 5. Simulation results for female workforce participation rate: controlling for scheduled tribes

\begin{tabular}{|c|c|c|c|c|c|c|c|c|}
\hline District & $\mathrm{AC}$ & PR & So & $\mathrm{S} 1$ & $\mathrm{~S} 2$ & S3 & S4 & S5 \\
\hline Balaghat & 45 & 35.8 & 32.5 & 32.8 & 33.6 & 33.6 & 33.6 & 33.6 \\
\hline Bastar & 49 & 49.0 & 48.1 & 48.3 & 48.7 & 48.7 & 48.7 & 48.7 \\
\hline Betul & 40 & 33.7 & 36.0 & 36.4 & 37.5 & 37.5 & 37.5 & 37.5 \\
\hline Bhind & 4 & 4.4 & 6.3 & 6.5 & 6.9 & 6.9 & 6.9 & 6.9 \\
\hline Bhopal & 14 & 11.5 & 15.4 & 15.9 & 16.5 & 16.5 & 16.5 & 16.5 \\
\hline Bilaspur & 37 & 34.9 & 33.4 & 33.7 & 34.2 & 34.2 & 34.2 & 34.2 \\
\hline Chhatarpur & 29 & 27.5 & 27.6 & 27.8 & 28.3 & 28.3 & 28.3 & 28.3 \\
\hline Chhindwara & 34 & 33.9 & 37.4 & 37.7 & 38.2 & 38.2 & 38.2 & 38.2 \\
\hline Damoh & 28 & 29.8 & 28.5 & 28.8 & 29.8 & 29.8 & 29.8 & 29.8 \\
\hline Datia & 20 & 28.9 & 27.5 & 27.7 & 28.0 & 28.0 & 28.0 & 28.0 \\
\hline Dewas & 30 & 32.5 & 31.2 & 31.5 & 31.9 & 31.9 & 31.9 & 31.9 \\
\hline Dhar & 40 & 42.1 & 44.0 & 44.2 & 44.5 & 44.5 & 44.5 & 44.5 \\
\hline Durg & 37 & 31.2 & 30.6 & 31.0 & 31.5 & 31.5 & 31.5 & 31.5 \\
\hline Guna & 21 & 28.7 & 30.7 & 30.9 & 31.2 & 31.2 & 31.2 & 31.2 \\
\hline Gwalior & 11 & 14.0 & 15.9 & 16.3 & 16.7 & 16.7 & 16.7 & 16.7 \\
\hline Hshbad & 23 & 31.1 & 31.4 & 31.7 & 32.4 & 32.4 & 32.4 & 32.4 \\
\hline Indore & 16 & 17.2 & 16.4 & 16.9 & 17.5 & 17.5 & 17.5 & 17.5 \\
\hline Jabalpur & 23 & 30.0 & 31.5 & 31.9 & 32.7 & 32.7 & 32.7 & 32.7 \\
\hline Jhabua & 52 & 48.3 & 53.6 & 53.7 & 54.2 & 54.2 & 54.2 & 54.2 \\
\hline Mandla & 47 & 47.8 & 44.2 & 44.4 & 45.3 & 45.3 & 45.3 & 45.3 \\
\hline Mandsaur & 38 & 33.4 & 28.2 & 28.4 & 28.8 & 28.8 & 28.8 & 28.8 \\
\hline Morena & 12 & 11.3 & 16.6 & 16.8 & 17.2 & 17.2 & 17.2 & 17.2 \\
\hline Narsmpur & 25 & 32.6 & 31.1 & 31.5 & 31.9 & 31.9 & 31.9 & 31.9 \\
\hline NimarE & 34 & 32.3 & 33.6 & 33.9 & 34.7 & 34.7 & 34.7 & 34.7 \\
\hline NimarW & 39 & 39.3 & 37.9 & 38.2 & 39.5 & 39.5 & 39.5 & 39.5 \\
\hline Panna & 29 & 30.1 & 31.3 & 31.4 & 31.9 & 31.9 & 31.9 & 31.9 \\
\hline Raigarh & 41 & 44.3 & 41.7 & 42.0 & 42.5 & 42.5 & 42.5 & 42.5 \\
\hline Raipur & 41 & 34.9 & 32.4 & 32.7 & 33.2 & 33.2 & 33.2 & 33.2 \\
\hline Raisen & 22 & 26.5 & 30.5 & 30.8 & 31.3 & 31.3 & 31.3 & 31.3 \\
\hline Rajgarh & 38 & 30.8 & 27.1 & 27.2 & 27.7 & 27.7 & 27.7 & 27.7 \\
\hline Rajnangn & 50 & 37.8 & 34.5 & 34.7 & 35.2 & 35.2 & 35.2 & 35.2 \\
\hline Ratlam & 37 & 34.6 & 34.5 & 34.8 & 35.1 & 35.1 & 35.1 & 35.1 \\
\hline Rewa & 29 & 28.2 & 30.2 & 30.5 & 31.0 & 31.0 & 31.0 & 31.0 \\
\hline Sagar & 26 & 25.1 & 27.7 & 28.0 & 28.9 & 28.9 & 28.9 & 28.9 \\
\hline Sarguja & 38 & 46.4 & 42.9 & 43.1 & 43.7 & 43.7 & 43.7 & 43.7 \\
\hline Satna & 30 & 28.8 & 30.7 & 31.0 & 31.5 & 31.5 & 31.5 & 31.5 \\
\hline Sehore & 32 & 30.8 & 29.1 & 29.3 & 29.9 & 29.9 & 29.9 & 29.9 \\
\hline Seoni & 44 & 39.2 & 37.8 & 38.1 & 38.7 & 38.7 & 38.7 & 38.7 \\
\hline Shahdol & 33 & 40.6 & 40.8 & 41.0 & 41.6 & 41.6 & 41.6 & 41.6 \\
\hline Shajapur & 35 & 30.5 & 27.4 & 27.6 & 27.9 & 27.9 & 27.9 & 27.9 \\
\hline Shivpuri & 30 & 31.6 & 30.5 & 30.7 & 31.0 & 31.0 & 31.0 & 31.0 \\
\hline Sidhi & 34 & 33.6 & 35.3 & 35.4 & 36.1 & 36.1 & 36.1 & 36.1 \\
\hline Tikamgarh & 33 & 25.0 & 27.9 & 28.1 & 28.5 & 28.5 & 28.5 & 28.5 \\
\hline Ujjain & 26 & 31.3 & 27.6 & 27.9 & 28.3 & 28.3 & 28.3 & 28.3 \\
\hline Vidisha & 21 & 26.1 & 27.3 & 27.6 & 28.2 & 28.2 & 28.2 & 28.2 \\
\hline
\end{tabular}

the female literacy rate raised, as discussed above, the female participation rate and therefore pushed up the child participation rate.

Reducing the poverty rate (simulation 2) had several effects. First, via equations (6) and (7), it lowered the fertility rate and the incidence of higher order births (Tables 3 and 4). The reduction in fertility rates increased, via equation (3), the female workforce participation rate (Table 5) and, in turn, this increased the child participation rate 
Table 6. Simulation results for children's workforce participation rate, main or marginal: controlling for scheduled tribes

\begin{tabular}{|c|c|c|c|c|c|c|c|c|}
\hline District & $\mathrm{AC}$ & PR & SO & $\mathrm{S} 1$ & $\mathrm{~S} 2$ & S3 & $\mathrm{S} 4$ & S5 \\
\hline Balaghat & 6.7 & 5.9 & 3.5 & 3.1 & 3.3 & 4.0 & 4.0 & 4.0 \\
\hline Bastar & 17.7 & 15.9 & 15.7 & 15.5 & 15.6 & 16.2 & 16.2 & 16.2 \\
\hline Betul & 13.8 & 10.7 & 9.9 & 9.6 & 9.8 & 10.4 & 10.4 & 10.4 \\
\hline Bhind & 1.7 & 1.3 & 1.7 & 1.3 & 1.4 & 1.9 & 1.9 & 1.9 \\
\hline Bhopal & 2.5 & 2.6 & 2.9 & 2.5 & 2.6 & 3.1 & 3.1 & 3.1 \\
\hline Bilaspur & 6.5 & 7.5 & 6.8 & 6.4 & 6.5 & 7.1 & 7.1 & 7.1 \\
\hline Chhatarpur & 8.5 & 8.0 & 7.8 & 7.5 & 7.5 & 8.1 & 8.1 & 8.1 \\
\hline Chhindwara & 10.5 & 10.0 & 10.6 & 10.3 & 10.4 & 10.9 & 10.9 & 10.9 \\
\hline Damoh & 6.4 & 5.6 & 5.7 & 5.3 & 5.5 & 6.1 & 6.1 & 6.1 \\
\hline Datia & 4.8 & 4.9 & 6.3 & 5.9 & 5.9 & 6.5 & 6.5 & 6.5 \\
\hline Dewas & 6.2 & 7.2 & 7.4 & 7.0 & 7.1 & 7.7 & 7.7 & 7.7 \\
\hline Dhar & 11.4 & 13.4 & 14.2 & 13.9 & 14.0 & 14.5 & 14.5 & 14.5 \\
\hline Durg & 5.5 & 6.2 & 5.0 & 4.5 & 4.6 & 5.2 & 5.2 & 5.2 \\
\hline Guna & 5.4 & 6.3 & 8.1 & 7.8 & 7.8 & 8.4 & 8.4 & 8.4 \\
\hline Gwalior & 2.9 & 1.7 & 2.7 & 2.2 & 2.3 & 2.9 & 2.9 & 2.9 \\
\hline Hshbad & 5.9 & 5.4 & 7.0 & 6.6 & 6.8 & 7.3 & 7.3 & 7.3 \\
\hline Indore & 3.1 & 2.3 & 2.4 & 1.9 & 2.0 & 2.6 & 2.6 & 2.6 \\
\hline Jabalpur & 3.8 & 4.4 & 6.0 & 5.5 & 5.7 & 6.3 & 6.3 & 6.3 \\
\hline Jhabua & 25.5 & 20.8 & 21.1 & 20.9 & 21.0 & 21.5 & 21.5 & 21.5 \\
\hline Mandla & 10.3 & 13.8 & 13.2 & 12.9 & 13.1 & 13.7 & 13.7 & 13.7 \\
\hline Mandsaur & 9.3 & 8.1 & 6.3 & 5.8 & 5.9 & 6.4 & 6.4 & 6.4 \\
\hline Morena & 3.8 & 4.3 & 5.2 & 4.8 & 4.9 & 5.4 & 5.4 & 5.4 \\
\hline Narsmpur & 5.4 & 6.0 & 7.2 & 6.8 & 6.9 & 7.4 & 7.4 & 7.4 \\
\hline NimarE & 10.6 & 10.0 & 10.0 & 9.6 & 9.8 & 10.3 & 10.3 & 10.3 \\
\hline NimarW & 12.6 & 13.5 & 13.3 & 13.0 & 13.2 & 13.8 & 13.8 & 13.8 \\
\hline Panna & 7.9 & 8.5 & 9.0 & 8.7 & 8.7 & 9.3 & 9.3 & 9.3 \\
\hline Raigarh & 9.7 & 11.3 & 11.5 & 11.1 & 11.2 & 11.8 & 11.8 & 11.8 \\
\hline Raipur & 7.6 & 8.3 & 6.7 & 6.3 & 6.3 & 7.0 & 7.0 & 7.0 \\
\hline Raisen & 4.9 & 6.4 & 8.0 & 7.7 & 7.8 & 8.4 & 8.4 & 8.4 \\
\hline Rajgarh & 11.2 & 9.2 & 7.1 & 6.8 & 6.9 & 7.5 & 7.5 & 7.5 \\
\hline Rajnangn & 11.2 & 11.2 & 8.2 & 7.9 & 7.9 & 8.5 & 8.5 & 8.5 \\
\hline Ratlam & 12 & 9.8 & 9.3 & 8.9 & 9.0 & 9.6 & 9.6 & 9.6 \\
\hline Rewa & 5.5 & 4.7 & 5.0 & 4.6 & 4.7 & 5.4 & 5.4 & 5.4 \\
\hline Sagar & 5.3 & 4.8 & 5.1 & 4.7 & 4.8 & 5.4 & 5.4 & 5.4 \\
\hline Sarguja & 11.1 & 13.0 & 13.9 & 13.6 & 13.7 & 14.3 & 14.3 & 14.3 \\
\hline Satna & 5.8 & 6.1 & 6.3 & 5.9 & 6.0 & 6.6 & 6.6 & 6.6 \\
\hline Sehore & 6.6 & 7.9 & 7.3 & 6.9 & 7.0 & 7.6 & 7.6 & 7.6 \\
\hline Seoni & 10.7 & 11.0 & 9.9 & 9.5 & 9.6 & 10.2 & 10.2 & 10.2 \\
\hline Shahdol & 7.9 & 9.8 & 11.3 & 11.0 & 11.1 & 11.7 & 11.7 & 11.7 \\
\hline Shajapur & 8.4 & 7.5 & 6.1 & 5.7 & 5.7 & 6.3 & 6.3 & 6.3 \\
\hline Shivpuri & 8 & 9.2 & 9.3 & 9.0 & 9.0 & 9.5 & 9.5 & 9.5 \\
\hline Sidhi & 8.5 & 8.9 & 9.2 & 8.9 & 9.0 & 9.7 & 9.7 & 9.7 \\
\hline Tikamgarh & 7.7 & 9.6 & 8.6 & 8.3 & 8.4 & 8.9 & 8.9 & 8.9 \\
\hline Ujjain & 6.6 & 5.2 & 5.6 & 5.1 & 5.2 & 5.8 & 5.8 & 5.8 \\
\hline Vidisha & 5.5 & 4.6 & 5.8 & 5.4 & 5.5 & 6.1 & 6.1 & 6.1 \\
\hline
\end{tabular}

(Tables 6 and 7 ). But the reduction in the poverty rate also had a direct effect (equation (2)) on reducing the child participation rate as main workers. The lower incidence of higher order births reduced, via equation (4), the child mortality rate (Table 8). Second, via equations (4) and (5), lower rates of poverty had a direct impact in lowering child and infant mortality rates (Tables 8 and 9). Reducing the degree of inequality in 
Table 7. Simulation results for children's workforce participation rate, main: controlling for scheduled tribes

\begin{tabular}{|c|c|c|c|c|c|c|c|c|}
\hline District & $\mathrm{AC}$ & PR & So & $\mathrm{S} 1$ & $\mathrm{~S} 2$ & S3 & $\mathrm{S} 4$ & S5 \\
\hline Balaghat & 5 & 5.0 & 3.1 & 3.0 & 3.0 & 3.5 & 3.5 & 3.5 \\
\hline Bastar & 13.4 & 10.7 & 10.5 & 10.5 & 10.5 & 10.9 & 10.9 & 10.9 \\
\hline Betul & 11.2 & 8.3 & 7.7 & 7.6 & 7.6 & 8.0 & 8.0 & 8.0 \\
\hline Bhind & 1.5 & 0.8 & 1.2 & 1.1 & 1.1 & 1.5 & 1.5 & 1.5 \\
\hline Bhopal & 1.8 & 2.4 & 2.6 & 2.6 & 2.5 & 3.0 & 3.0 & 3.0 \\
\hline Bilaspur & 4.7 & 5.7 & 5.2 & 5.1 & 5.1 & 5.5 & 5.5 & 5.5 \\
\hline Chhatarpur & 5.5 & 5.4 & 5.2 & 5.1 & 5.1 & 5.5 & 5.5 & 5.5 \\
\hline Chhindwara & 7.9 & 7.3 & 7.8 & 7.7 & 7.7 & 8.1 & 8.1 & 8.1 \\
\hline Damoh & 4.9 & 4.5 & 4.6 & 4.5 & 4.4 & 4.9 & 4.9 & 4.9 \\
\hline Datia & 2.9 & 3.4 & 4.5 & 4.4 & 4.4 & 4.8 & 4.8 & 4.8 \\
\hline Dewas & 4.8 & 5.3 & 5.5 & 5.4 & 5.4 & 5.8 & 5.8 & 5.8 \\
\hline Dhar & 8.7 & 9.3 & 9.9 & 9.9 & 9.8 & 10.3 & 10.3 & 10.3 \\
\hline Durg & 4.8 & 5.2 & 4.2 & 4.1 & 4.1 & 4.6 & 4.6 & 4.6 \\
\hline Guna & 3.7 & 3.9 & 5.4 & 5.3 & 5.3 & 5.8 & 5.8 & 5.8 \\
\hline Gwalior & 2.3 & 1.5 & 2.2 & 2.1 & 2.1 & 2.5 & 2.5 & 2.5 \\
\hline Hshbad & 4.3 & 4.3 & 5.6 & 5.5 & 5.5 & 5.9 & 5.9 & 5.9 \\
\hline Indore & 2.7 & 2.3 & 2.4 & 2.3 & 2.3 & 2.7 & 2.7 & 2.7 \\
\hline Jabalpur & 2.9 & 3.8 & 5.1 & 5.0 & 5.0 & 5.4 & 5.4 & 5.4 \\
\hline Jhabua & 15.2 & 14.1 & 14.3 & 14.3 & 14.2 & 14.6 & 14.6 & 14.6 \\
\hline Mandla & 8.5 & 10.2 & 9.8 & 9.7 & 9.7 & 10.1 & 10.1 & 10.1 \\
\hline Mandsaur & 7.4 & 6.4 & 4.9 & 4.8 & 4.8 & 5.2 & 5.2 & 5.2 \\
\hline Morena & 3.1 & 2.8 & 3.5 & 3.4 & 3.4 & 3.8 & 3.8 & 3.8 \\
\hline Narsmpur & 4.1 & 4.7 & 5.6 & 5.5 & 5.5 & 5.9 & 5.9 & 5.9 \\
\hline NimarE & 8.5 & 7.7 & 7.6 & 7.5 & 7.5 & 7.9 & 7.9 & 7.9 \\
\hline NimarW & 9.8 & 10.1 & 10.0 & 9.9 & 9.8 & 10.2 & 10.2 & 10.2 \\
\hline Panna & 5.6 & 5.7 & 6.0 & 6.0 & 6.0 & 6.4 & 6.4 & 6.4 \\
\hline Raigarh & 6.5 & 8.2 & 8.3 & 8.2 & 8.2 & 8.7 & 8.7 & 8.7 \\
\hline Raipur & 6.1 & 6.4 & 5.1 & 5.0 & 5.0 & 5.5 & 5.5 & 5.5 \\
\hline Raisen & 3.6 & 4.5 & 5.8 & 5.7 & 5.7 & 6.1 & 6.1 & 6.1 \\
\hline Rajgarh & 7.2 & 6.4 & 4.7 & 4.7 & 4.6 & 5.1 & 5.1 & 5.1 \\
\hline Rajnangn & 9.4 & 8.5 & 6.1 & 6.1 & 6.0 & 6.5 & 6.5 & 6.5 \\
\hline Ratlam & 8.3 & 7.1 & 6.7 & 6.6 & 6.6 & 7.0 & 7.0 & 7.0 \\
\hline Rewa & 4 & 3.5 & 3.7 & 3.6 & 3.6 & 4.1 & 4.1 & 4.1 \\
\hline Sagar & 3.9 & 4.1 & 4.3 & 4.2 & 4.2 & 4.7 & 4.7 & 4.7 \\
\hline Sarguja & 6.9 & 8.9 & 9.7 & 9.6 & 9.6 & 10.0 & 10.0 & 10.0 \\
\hline Satna & 4.4 & 4.5 & 4.6 & 4.5 & 4.5 & 5.0 & 5.0 & 5.0 \\
\hline Sehore & 4.7 & 5.8 & 5.4 & 5.3 & 5.2 & 5.7 & 5.7 & 5.7 \\
\hline Seoni & 8.2 & 8.2 & 7.3 & 7.2 & 7.2 & 7.6 & 7.6 & 7.6 \\
\hline Shahdol & 5.6 & 6.7 & 7.9 & 7.8 & 7.8 & 8.3 & 8.3 & 8.3 \\
\hline Shajapur & 6 & 5.4 & 4.3 & 4.2 & 4.2 & 4.6 & 4.6 & 4.6 \\
\hline Shivpuri & 5.6 & 6.2 & 6.2 & 6.2 & 6.1 & 6.5 & 6.5 & 6.5 \\
\hline Sidhi & 5.6 & 6.0 & 6.2 & 6.1 & 6.1 & 6.6 & 6.6 & 6.6 \\
\hline Tikamgarh & 5 & 6.6 & 5.8 & 5.7 & 5.7 & 6.1 & 6.1 & 6.1 \\
\hline Ujjain & 5 & 3.9 & 4.2 & 4.1 & 4.1 & 4.5 & 4.5 & 4.5 \\
\hline Vidisha & 3.9 & 3.3 & 4.3 & 4.2 & 4.2 & 4.6 & 4.6 & 4.6 \\
\hline
\end{tabular}

the distribution of land-holdings (simulation 3), unlike poverty reduction, had a single effect: acting through equations (1) and (2), it increased the workforce participation rate of children (Tables 6 and 7). However, in assessing this result, the possibility that inequality reduction might be an important instrument for reducing poverty should not be discounted. 
Table 8. Simulation results for child mortality rates: controlling for scheduled tribes

\begin{tabular}{|c|c|c|c|c|c|c|c|c|}
\hline District & $\mathrm{AC}$ & PR & so & $\mathrm{S} 1$ & S2 & S3 & S4 & S5 \\
\hline Balaghat & 167 & 131.8 & 153.0 & 132.0 & 124.4 & 124.4 & 124.4 & 118.9 \\
\hline Bastar & 129 & 126.6 & 127.7 & 119.5 & 115.2 & 115.2 & 115.2 & 104.4 \\
\hline Betul & 180 & 188.1 & 174.5 & 156.2 & 145.2 & 145.2 & 145.2 & 140.6 \\
\hline Bhind & 149 & 167.1 & 159.0 & 143.8 & 140.2 & 140.2 & 140.2 & 134.8 \\
\hline Bhopal & 105 & 128.8 & 115.5 & 86.4 & 80.3 & 80.3 & 80.3 & 69.9 \\
\hline Bilaspur & 123 & 119.2 & 123.2 & 108.5 & 102.9 & 102.9 & 102.9 & 90.9 \\
\hline Chhatarpur & 199 & 194.8 & 180.4 & 169.0 & 164.8 & 164.8 & 164.8 & 160.1 \\
\hline Chhindwara & 142 & 150.0 & 133.4 & 115.9 & 110.7 & 110.7 & 110.7 & 101.9 \\
\hline Damoh & 194 & 189.8 & 191.9 & 175.6 & 166.3 & 166.3 & 166.3 & 163.4 \\
\hline Datia & 178 & 177.5 & 178.8 & 166.1 & 163.1 & 163.1 & 163.1 & 160.4 \\
\hline Dewas & 129 & 158.6 & 168.3 & 154.5 & 150.1 & 150.1 & 150.1 & 145.3 \\
\hline Dhar & 122 & 142.3 & 135.9 & 124.7 & 121.1 & 121.1 & 121.1 & 115.4 \\
\hline Durg & 122 & 121.3 & 128.4 & 105.4 & 100.6 & 100.6 & 100.6 & 93.0 \\
\hline Guna & 195 & 175.2 & 171.3 & 161.6 & 158.6 & 158.6 & 158.6 & 152.7 \\
\hline Gwalior & 119 & 154.0 & 153.7 & 131.3 & 127.2 & 127.2 & 127.2 & 122.4 \\
\hline Hshbad & 179 & 166.9 & 153.4 & 133.2 & 126.5 & 126.5 & 126.5 & 119.8 \\
\hline Indore & 94 & 122.4 & 127.5 & 98.8 & 93.3 & 93.3 & 93.3 & 86.4 \\
\hline Jabalpur & 147 & 142.4 & 130.7 & 106.5 & 99.4 & 99.4 & 99.4 & 90.7 \\
\hline Jhabua & 169 & 177.2 & 150.3 & 144.1 & 138.8 & 138.8 & 138.8 & 133.7 \\
\hline Mandla & 132 & 134.1 & 159.4 & 147.4 & 138.4 & 138.4 & 138.4 & 132.5 \\
\hline Mandsaur & 150 & 134.2 & 154.1 & 138.9 & 134.9 & 134.9 & 134.9 & 127.7 \\
\hline Morena & 138 & 185.8 & 171.7 & 160.6 & 157.1 & 157.1 & 157.1 & 151.5 \\
\hline Narsmpur & 148 & 150.8 & 148.8 & 126.5 & 122.7 & 122.7 & 122.7 & 118.5 \\
\hline NimarE & 151 & 154.6 & 151.3 & 134.4 & 126.0 & 126.0 & 126.0 & 118.1 \\
\hline NimarW & 158 & 142.8 & 151.9 & 139.5 & 126.7 & 126.7 & 126.7 & 115.9 \\
\hline Panna & 204 & 182.1 & 188.0 & 177.6 & 173.6 & 173.6 & 173.6 & 170.9 \\
\hline Raigarh & 131 & 127.0 & 139.4 & 125.2 & 120.4 & 120.4 & 120.4 & 113.5 \\
\hline Raipur & 137 & 120.5 & 126.0 & 109.3 & 104.9 & 104.9 & 104.9 & 94.6 \\
\hline Raisen & 179 & 177.0 & 179.0 & 165.3 & 159.6 & 159.6 & 159.6 & 155.4 \\
\hline Rajgarh & 182 & 169.1 & 186.4 & 178.0 & 173.2 & 173.2 & 173.2 & 168.3 \\
\hline Rajnangn & 150 & 143.6 & 160.8 & 145.9 & 141.0 & 141.0 & 141.0 & 136.2 \\
\hline Ratlam & 149 & 131.2 & 132.7 & 117.1 & 113.9 & 113.9 & 113.9 & 105.0 \\
\hline Rewa & 196 & 179.9 & 171.0 & 156.6 & 151.6 & 151.6 & 151.6 & 148.4 \\
\hline Sagar & 172 & 177.1 & 161.7 & 141.4 & 132.7 & 132.7 & 132.7 & 125.7 \\
\hline Sarguja & 113 & 142.6 & 151.9 & 142.5 & 136.4 & 136.4 & 136.4 & 128.7 \\
\hline Satna & 203 & 163.8 & 161.6 & 146.6 & 141.8 & 141.8 & 141.8 & 136.5 \\
\hline Sehore & 178 & 178.8 & 181.4 & 169.6 & 163.9 & 163.9 & 163.9 & 159.0 \\
\hline Seoni & 152 & 150.5 & 154.2 & 137.5 & 131.3 & 131.3 & 131.3 & 126.1 \\
\hline Shahdol & 160 & 163.2 & 161.6 & 150.8 & 145.2 & 145.2 & 145.2 & 139.3 \\
\hline Shajapur & 168 & 160.9 & 176.0 & 165.4 & 161.8 & 161.8 & 161.8 & 156.8 \\
\hline Shivpuri & 200 & 190.3 & 181.4 & 173.0 & 170.3 & 170.3 & 170.3 & 166.2 \\
\hline Sidhi & 165 & 183.0 & 178.4 & 171.1 & 165.0 & 165.0 & 165.0 & 159.7 \\
\hline Tikamgarh & 187 & 180.4 & 178.2 & 167.4 & 163.9 & 163.9 & 163.9 & 160.0 \\
\hline Ujjain & 147 & 124.9 & 134.6 & 117.1 & 113.7 & 113.7 & 113.7 & 103.8 \\
\hline Vidisha & 191 & 201.0 & 184.7 & 169.8 & 164.0 & 164.0 & 164.0 & 160.3 \\
\hline
\end{tabular}

Improving access to safe drinking water (simulation 4) had the important effect of reducing infant mortality rates (Table 9), and improving infrastructure with respect to health centres - both in terms of access and in terms of bed capacity-reduced child and infant mortality rates (Tables 8 and 9). 
Table 9. Simulation results for infant mortality rates: Controlling for scheduled tribes

\begin{tabular}{|c|c|c|c|c|c|c|c|c|}
\hline District & $\mathrm{AC}$ & PR & so & $\mathrm{S} 1$ & $\mathrm{~S} 2$ & S3 & S4 & S5 \\
\hline Balaghat & 141 & 142.6 & 134.5 & 134.7 & 127.9 & 127.9 & 113.2 & 110.9 \\
\hline Bastar & 98 & 93.2 & 92.6 & 92.7 & 88.9 & 88.9 & 77.4 & 72.2 \\
\hline Betul & 146 & 141.1 & 138.6 & 138.8 & 128.9 & 128.9 & 120.0 & 118.0 \\
\hline Bhind & 105 & 111.7 & 113.2 & 113.4 & 110.1 & 110.1 & 94.5 & 92.3 \\
\hline Bhopal & 94 & 97.9 & 98.8 & 99.1 & 93.6 & 93.6 & 93.4 & 88.5 \\
\hline Bilaspur & 109 & 108.3 & 106.0 & 106.1 & 101.1 & 101.1 & 90.4 & 84.8 \\
\hline Chhatarpur & 136 & 133.1 & 132.2 & 132.4 & 128.6 & 128.6 & 108.8 & 106.7 \\
\hline Chhindwara & 119 & 106.6 & 108.7 & 108.9 & 104.3 & 104.3 & 94.5 & 90.4 \\
\hline Damoh & 166 & 148.8 & 149.1 & 149.3 & 141.0 & 141.0 & 125.8 & 124.7 \\
\hline Datia & 131 & 119.3 & 124.1 & 124.3 & 121.6 & 121.6 & 111.9 & 111.0 \\
\hline Dewas & 97 & 117.6 & 118.4 & 118.6 & 114.6 & 114.6 & 107.3 & 105.3 \\
\hline Dhar & 99 & 101.3 & 103.9 & 104.0 & 100.8 & 100.8 & 95.7 & 93.7 \\
\hline Durg & 102 & 116.1 & 112.0 & 112.2 & 108.0 & 108.0 & 102.4 & 99.1 \\
\hline Guna & 124 & 107.4 & 113.6 & 113.7 & 111.0 & 111.0 & 100.4 & 97.6 \\
\hline Gwalior & 96 & 108.5 & 111.7 & 112.0 & 108.3 & 108.3 & 101.4 & 99.3 \\
\hline Hshbad & 138 & 117.0 & 122.4 & 122.6 & 116.6 & 116.6 & 107.6 & 104.6 \\
\hline Indore & 71 & 105.3 & 105.6 & 105.9 & 101.0 & 101.0 & 100.7 & 97.7 \\
\hline Jabalpur & 121 & 111.7 & 117.2 & 117.5 & 111.1 & 111.1 & 104.3 & 100.4 \\
\hline Jhabua & 92 & 103.3 & 104.3 & 104.3 & 99.7 & 99.7 & 92.0 & 90.1 \\
\hline Mandla & 114 & 131.3 & 129.5 & 129.6 & 121.5 & 121.5 & 106.3 & 103.9 \\
\hline Mandsaur & 111 & 123.7 & 117.4 & 117.6 & 114.0 & 114.0 & 102.2 & 98.9 \\
\hline Morena & 118 & 110.0 & 113.0 & 113.1 & 110.0 & 110.0 & 96.3 & 93.8 \\
\hline Narsmpur & 120 & 109.2 & 113.1 & 113.4 & 109.9 & 109.9 & 108.3 & 106.6 \\
\hline NimarE & 129 & 121.7 & 121.4 & 121.6 & 114.1 & 114.1 & 107.8 & 104.4 \\
\hline NimarW & 126 & 125.7 & 125.0 & 125.1 & 113.8 & 113.8 & 107.0 & 102.0 \\
\hline Panna & 132 & 131.2 & 132.6 & 132.8 & 129.2 & 129.2 & 110.9 & 109.8 \\
\hline Raigarh & 112 & 113.7 & 114.2 & 114.3 & 110.0 & 110.0 & 95.3 & 92.4 \\
\hline Raipur & 121 & 112.8 & 107.3 & 107.5 & 103.6 & 103.6 & 92.9 & 88.2 \\
\hline Raisen & 141 & 120.9 & 126.4 & 126.6 & 121.4 & 121.4 & 111.9 & 110.1 \\
\hline Rajgarh & 125 & 131.6 & 124.6 & 124.7 & 120.3 & 120.3 & 110.6 & 108.5 \\
\hline Rajnangn & 129 & 131.3 & 121.2 & 121.4 & 117.1 & 117.1 & 105.9 & 103.9 \\
\hline Ratlam & 128 & 97.7 & 96.1 & 96.2 & 93.4 & 93.4 & 91.3 & 87.2 \\
\hline Rewa & 149 & 136.3 & 137.1 & 137.3 & 132.8 & 132.8 & 114.4 & 113.4 \\
\hline Sagar & 138 & 134.9 & 136.0 & 136.2 & 128.4 & 128.4 & 114.6 & 111.4 \\
\hline Sarguja & 92 & 115.3 & 118.5 & 118.6 & 113.1 & 113.1 & 94.7 & 91.2 \\
\hline Satna & 142 & 128.9 & 129.4 & 129.5 & 125.2 & 125.2 & 107.7 & 105.5 \\
\hline Sehore & 125 & 127.9 & 126.1 & 126.2 & 121.1 & 121.1 & 111.0 & 108.9 \\
\hline Seoni & 126 & 128.0 & 124.0 & 124.2 & 118.7 & 118.7 & 105.9 & 103.7 \\
\hline Shahdol & 137 & 117.9 & 123.0 & 123.1 & 118.1 & 118.1 & 99.5 & 96.8 \\
\hline Shajapur & 116 & 123.4 & 118.4 & 118.6 & 115.4 & 115.4 & 107.1 & 105.0 \\
\hline Shivpuri & 120 & 116.6 & 116.9 & 117.0 & 114.6 & 114.6 & 104.3 & 102.5 \\
\hline Sidhi & 111 & 129.0 & 129.8 & 129.9 & 124.4 & 124.4 & 106.5 & 104.3 \\
\hline Tikamgarh & 142 & 135.8 & 132.6 & 132.7 & 129.5 & 129.5 & 110.3 & 108.9 \\
\hline Ujjain & 77 & 98.3 & 99.4 & 99.6 & 96.5 & 96.5 & 94.1 & 89.4 \\
\hline Vidisha & 107 & 129.2 & 133.3 & 133.4 & 128.3 & 128.3 & 115.3 & 113.7 \\
\hline
\end{tabular}

\section{Conclusions}

The issue of "women's agency" - of which the two most important aspects are women's education and women's paid employment-has, in the context of improving the position of women and the welfare of their children, received considerable attention in the development studies literature (Drèze \& Sen, 1999; Drèze et al., 1995; Murthi et 
al., 1995). Their results suggested that higher levels of female labour-force participation reduced the gender bias in child survival but did not have a statistically significant effect on the level of child (under five) mortality; on the other, hand, higher rates of female literacy unambiguously reduced child mortality. This paper supports the finding that higher rates of female participation do not affect the child mortality rate, but it does suggest that the rate of infant mortality is adversely affected. In other words, an important result from this study is that maternal care is significantly more important for the survival of infants than it is for the survival of older children and that the supply of such care is diminished, to the detriment of infants, through women's paid employment.

On the issue of literacy, the line of causation, pursued in this paper, was more complex: female literacy and participation rates were linked through female reproductive behaviour, with a further link existing between female participation rates and infant and child mortality rates. ${ }^{16}$ Higher rates of female literacy affected the reproductive behaviour of women in a way that enhanced their welfare: both fertility rates and the proportion of higher order births, in total births, fell in consequence of higher literacy. With several young children in the family, a mother's available time, and the household's resources allocated to children, would mostly be spent on infants, and older children could be neglected. Consequently, when the proportion of higher order births fell, women had more time and resources to devote to their older children, and the child (under five) mortality rate fell. In that sense, within the analytical framework of this study, rates of female literacy and child mortality were negatively correlated. This result is consistent with that of LeGrand \& Phillips (1996) who found that, in Bangladesh, fertility reductions lessened the mortality of children between the ages of two and five but did not affect infant mortality. However, the position with respect to infant mortality was different. Higher rates of female literacy lowered fertility rates and, by improving women's opportunities for paid employment, increased women's participation; but they also, independently of fertility rates, reduced women's participation, for reasons discussed earlier. The empirical finding of this paper was that the net effect of higher female literacy rates would be to increase participation by a small amount and, thereby, through the maternal care argument set out earlier, to slightly raise infant mortality rates.

This study's conclusion was that the role of women's agency in affecting infant mortality was dwarfed by the fact that the two biggest killers of infants in Madhya Pradesh were unsafe drinking water and poverty: the largest decreases in infant mortality could be achieved by allowing more households access to safe drinking water while simultaneously reducing the number of households in poverty. The result on the importance of safe drinking water supports the findings of Lee et al. (1997), who argued that conventional reduced-form econometric estimates, if anything, understated the importance of better sanitation and water quality on the health of children.

On the issue of child labour-the existence of which has raised much concern recently in Western Europe and the USA - the findings suggest that the representation of the phenomenon (as, for example, by Basu \& Van (1998)) as one driven by parental need allied to ignorance about the importance of "investing" in children, rather than by parental greed, is an accurate one. High levels of poverty and low rates of male adult literacy were associated with high rates of child participation. Overlying this, however, were two other factors. The first was the importance of family labour and the importance of child labour to the family's labour input in making small family-owned holdings economically viable: ceteris paribus districts with relatively low degrees of inequality in the distribution of land had relatively high rates of child participation. The second 
factor was "cultural": after controlling for other factors, districts with a high proportion of scheduled tribe persons in their population were those where child labour was most likely to be prevalent.

The Madhya Pradesh government has undertaken a number of policy initiatives to address the problem of a lack of human development in the state. Under the Education Guarantee Scheme all areas which do not have a school within $1 \mathrm{~km}$ can have one on demand. The Mission to Control Diarrhoeal Disease, prompted by the fact that 28\% of infant deaths in Madhya Pradesh were caused by diarrhoea, has taken as its aim a reduction in the incidence of water-borne disease through increased provision of, and access to, safe drinking water. A scheme of "barefoot doctors" (Jon Swastya Rakshak) has been in operation for 2 years to provide basic health care in villages. Against this background of pro-developmental policies, the contribution of this study has been to provide a quantitative assessment of their effects, particularly as they relate to the welfare of children in Madhya Pradesh.

\section{Notes}

1. Bimari being the Hindi word for a sick person.

2. As measured by the Gini coefficient of operational holdings. The value of the Gini coefficient ranged from 0.47 in West Nimar to 0.72 in Balaghat.

3. So termed because the Indian Constitution formally recognized the plight of the "untouchables" of Indian society by establishing their ethnic subgroups as scheduled castes ( 80 million) and scheduled tribes (38 million). Besides banning untouchability, the Constitution provides these groups with specific educational and vocation privileges and grants them special representation in the Indian Parliament.

4. Grass leaves, reeds, thatch, wood, mud, unburnt bricks.

5. Hospitals, community health centres, dispensaries, primary health centres and sub-health centres.

6. Though on women's participation note that Drèze et. al. (1995) have argued that paid employment could, by exposing women to outside influences, improve the quality of care they give their children.

7. See Zellner (1962).

8. In the absence of any cross-equation correlation between the errors there is, of course, no gain in efficiency.

9. See Greene (1993), p. 420 for a discussion of the symptoms of multicollinearity.

10. For example, any work involving domestic duties in a higher caste home is impossible.

11. The female participation, regardless of its origins, has also (as equations (1) and (2) show) an independent effect on the childrens' participation rate.

12. The simulations based on the estimates of Table 2 were qualitatively not very different from those reported, and for reasons of expositional ease are not shown.

13. These were the percentage gaps between the MP and the all-India literacy rates.

14. So, for example, simulation 2 measures the effect of reducing poverty, given the higher literacy rates of simulation 1.

15. In particular, $T F R$ and $B O 4$ were explanatory variables in, respectively, equations (3) and (4), and FPR was an explanatory variable in equations (1) and (2).

16. Such links were not considered in the studies cited earlier.

\section{References}

Ashagrie, K. (1993) Statistics on child labour, Bulletin of Labour Statistics, International Labour Organization), pp. 11-24.

Bailey, F.G. (1960) Tribe, Caste and Nation (Manchester; Manchester University Press).

Basu, K. \& Van, P.H. (1998) The economics of child labour, American Economic Review, 88, pp. 412-427.

Deliège, R. (1996) At the threshold of untouchability: pallars and valaiyars in a Tamil village, in:

C.J. Fuller (Ed.) Caste Today (Delhi; Oxford University Press). 
Drèze, J., Guio, A.C. \& Murthi, M. (1995) Demographic Outcomes, Economic Development and Women's Agency, Working Paper No. 28, Centre for Development Economics, Delhi School of Economics.

Drèze, J. \& Sen, A.K. (1999) India: Economic Development and Social Opportunity (New Delhi, Oxford University Press).

Government of Madhya Pradesh (1998) Human Development Report, 1998 (Bhopal, MPHDR Project Office).

Greene, W.H. (1993) Econometric Analysis (Englewood Cliffs, Prentice Hall).

Lee, L.F., Rosenweig, M.R. \& Pitt, M.M. (1997) The effects of improved nutrition, sanitation and water quality on child health in high mortality regions, Journal of Econometrics, 77, pp. 209-235.

LeGrand, T.K. \& Phillips, J.F. (1996) The effect of fertility reductions on infant and child mortality: evidence from Matlab in Bangladesh, Population Studies, 50, pp. 51-68.

Mahmood, M., Javaid, T. \& Baig, A. (1994) Why children do not go to school in Pakistan, Pakistan Development Review, 33, pp. 1231-1245.

Murthi, M., Guio, A.C. \& Drèze, J. (1995) Mortality, fertility and gender bias in India: a district-level analysis, Population and Development Review, 21, pp. 745-782.

Pattnaik, P.M. (1995) Status of women, infant mortality and birth rate-a correlative study, Indian Economic Journal, 42, pp. 116-121.

United Nations Development Programme (1998) Human Development Report, 1998, (New York, Oxford UniversityPress).

Weiner, M. (1991) The Child and the State in India: Child Labour and Education Policy in Comparative Perspective (Princeton, NJ, Princeton University Press).

White, B. (1996) Globalisation and the child labour problem, Journal of International Development, 8, pp. 829-839.

Zellner, A. (1962) An efficient method of estimating seemingly unrelated regressions and tests for aggregation bias, Journal of the American Statistical Association, 57, pp. 348-368. 